\title{
THE PALAEOLITHIC COLONIZATION OF EUROPE: AN ARCHAEOLOGICAL AND BIOGEOGRAPHIC PERSPECTIVE
}

\author{
BY
}

\author{
NICOLAS ROLLAND (*)
}

\begin{abstract}
Current knowledge on the Lower Palaeolithic peopling of Europe is synthesized, using toolmaking repertoires, geochronological, biogeographical and palaegeographic evidence. The oldest traces belong to a non-Acheulian horizon, dating between 0.90 to 0.55 my. Tracing hominid geographic origin and dispersal routes into Europe identifies three alternatives: through the Levant corridor, across Gibraltar strait or more remotely, from a Central Asia filter route. No conclusive proof exists for any of these but there is more coherent empirical support for Central Asia where a non-Acheulian industry is also present. In this alternative, ancient hominid colonization of Europe was synchronous with a major Pleistocene mamalian turnover, the end-Villafranchian/Galerian dispersal event, originating in Central Asia.
\end{abstract}

RESUMEN Sintetizamos el conocimiento actual sobre el poblamiento de Europa durante el Paleolítico inferior, empleando datos de repertorios líticos, así como evidencia geocronológica, biogeográfica y paleogeográfica. Los vestigios humanos más antiguos pertenecen a un horizonte no-Achelense con una edad entre 0.90 y 0.55 ma. Buscando el origen geográfico y los caminos de dispersión hasta Europa, identificamos tres alternativas: a través del corredor del Levante, del estrecho de Gibraltar o, más improbablemente, por un camino de tipo filtro desde Asia Central. No existen pruebas definitivas para ninguna de esas alternativas pero hay un apoyo empírico más coherente para la hipótesis de Asia Central, donde existe también un repertorio no-Achelense. Según esta alternativa, la colonización de Europa coincide con un importante cambio en la fauna pleistocénica, la dispersión del final del Villafranquiense/Galeriense, la cual también se originó en Asia Central.

Key words Lower Palaeolithic colonization of Europe. «Pebble-Culture». Acheulian. «Early European Palaeolithic Horizon". Handaxes/cleavers. Homo erectus. Biogeography. Mam. malian dispersal events. African carnivores. Dispersal corridor. Filter route. End-Villafranchian/Galerian dispersal event. Palaeogeography. Levant corridor. Maghreb. IberoMoroccan landbridge. Central Asia. Geochronology, Lower-middle Pleistocene. Jaramillo event. Late Matuyama epoch. Brunhes epoch.

Palabras clave Colonización europea durante el Paleolítico Inferior. "Cultura de cantos trabajados". Achelense. «Horizonte Paleolítico Inicial Europeon. Bifaces/Hendedores. Homo erectus. Biogeografia. Los casos de dispersión faunística. Carnívoros africanos. Corredor de dispersión. Camino filtro. El caso de la dispersión del Villafranquiense final/Galeriense. Paleogeografía. Corredor del Levante. Maghreb. Puente terrestre ibero-marroquí. Asia Central. Geocronología. Pleistoceno Inferior-Medio. Fase Jaramillo. Fase Matuyama final. Fase Brunhes.

(') Associate Professor Department of Anthropology The University of Victoria. Victoria. B.C., Canadá. 
"Investigations of why hominids migrated tend to confine themselves to analyses of archaeological and hominid fossil remains... Thus many investigations seek understanding of origins and dispersal routes solely in terms of archaeological affinities... Man was only one mammalian species among others which underwent significant dispersal during the Pleistocenen (Turner, 1982).

"The most outstanding of these faunal revolutions is the one which occurred at the end of the Villafranchian and the beginning of the Galerian. It was a real faunal revolution with an extinction episode and replacements by exotics in addition to rapid in-place evolution of native species... the development of a new faunal character throughout Eurasian (Guthrie, 1984).

sIt would seem, then, to be a well-established fact that south-eastern Asia contains a great industrial complex that has evolved differently from the bifacial complex. But this complex probably sent out feelers far to the west, by a route that is as yet imperfectly understood but which may have passed through the south of the Soviet Unionn (Bordes, 1968).

\section{INTRODUCTION}

The present paper provides a synthesis of evidence and hypotheses concerning the initial Lower Palaeolithic peopling of Europe. Syntheses on this theme are rare. Most tend to be concise and incidental statements (1) in the context of fieldwork reports. The colonization of Europe fits within the wider context of initial hominid dispersal out of Africa into Eurasia but whether this formed part of a single or two-stage event is still debated. Although Europe is geographically closer to Africa - the locus of human origins and starting point for movements into other continentsphysiographic and bioclimatic barriers could impede or delay the peopling of Europe. Most of the anthropic evidence concerning this event is archaeological rather than fossil. This raises practical and interpretative issues, ranging from taphonomy, identification, dating, to diagnosis of repertoires.

\section{MAJOR ISSUES AND FINDINGS}

Issues. We need first to establish the age, duration and characteristics of the earliest Lower Palaeolithic in Europe. A basic question, relating to the problem of identifying the point of immediate origin and penetration routes into Europe, is to specify conclusively the artifactual contents of this oldest horizon: does it belong, as was believed for long, to the widespread handaxe and cleaver or Acheulian technocomplex or, as is becoming more apparent, to a more archaic-looking «PebbleCulture" or "Pre-Acheulian" group? In the latter case, it may have derived directly from the more ancient Oldowan complex of Subsaharan Africa or illustrate more recent and distinct development.

Other issues include reconstructing population movement routes into Europe. The configuration of Eurasia, comprising the Mediterranean and the West-East trending of mountain barriers, as well as its latitudinal bioclimatic gradation, confined ancient hominid movements, not to mention the palaeogeographic repercussions of Pleistocene ice ages, such as glacio-eustatic sea level changes, continental ice sheet advances, southward spreads of periglacial environments and retreats of

(1) This research was carried out over several years and involved extensive bibliographic coverage, as well as examining artifact collections, visiting sites and discussions with principal investigators and specialists, mainly in Spain, France, Italy and to a more limited extent elsewhere in Europe and Southwest Asia. We gratefully acknowledge the assistance and/or valuable information from numerous individuals and institutions: in Spain: Carmen Cacho, Museo Aqueológico Nacional (Madrid), Manuel Santonja (Museo de Salamanca), Miguel Botella (University of Granada); in France, the late François Bordes, as well as Francois Prat, Jean-Paul Raynal, Institut du Quaternaire, Bordeaux University, Eugène and Marie-Francoise Bonifay, C.N.R.S. and Marseille-Luminy University, Alain Tuffreau, C.N.R.S. and Lille University, Henry de Lumley, I.P.H.; in Italy, Alberto Broglio, Carlo Peretto, Benedetto Sala, Ferrara University, Carlo Tozzi, Pisa University, Salvatore Marcuci, Visogliano site, Margherita Mussi, Amilcare Bietti, La Sapienza University, Rome, Italo Biddittu, Aldo Segre, Istituto Italiano di Paleontologia Umana, Rome, Anna Paola Anzidei, Soprintendenza Archeologica, Rome Patrizia Gioia, La Sapienza University, Rome, Grazia Maria Bulgareli and Marcello Piperno, Museo Luigi Pigorini, Rome, Giorgio Chelidonio, Verona; In Britain: Derek Roe, Oxford University, Jill Cook, British Museum; in Germany: Gerhard Bossinski, Villa Monrepos Research Institute, Neuwied; in Poland: Jan Michal, Burdukiewicz, Wroclaw University. Outside Europe: Ișin Yalçinkaya, Ankara University, Naama Goren, Hebrew University of Jerusalem and Moishe Prausnitz, Israel Museum, Jerusalem, Israel. 
vegetation belts. The articulation of such circumstances with the time-space distribution of distinct Lower Palaeolithic repertoires will constitute a complex but essential aspect of discussions.

It may also be rewarding to integrate ancient hominid colonization within a conceptual framework that will include biogeography and socioecology rather than isolating it within its archaeological dimension (Turner 1982, Rolland 1983). Hence, human emigrations out of Africa and within Eurasia may have been linked with major Pleistocene mammalian dispersal events such as the expansion of African carnivores into Eurasia or the vast replacement of Villafranchian by Quaternary or Galerian faunas within the Palaearctic region.

Findings. Available evidence suggests that the earliest Lower Palaeolithic in Europe reaches back to the late lower Pleistocene, from a time span equivalent with the Jaramillo normal polarity subchron, around 0.90-0.95 my, somewhat later than the oldest anthropic traces found in the Near East, Southeast Asia and China, which range from at least 1.25 to $1.10 \mathrm{my}$, thus indicating that Europe may have been colonized later.

The first Lower Palaeolithic horizon in Europe does not possess diagnostic elements i.e. handaxes, cleavers, of the Acheulian which appear there later. Current evidence throughout Eurasia and the Mediterranean basin, on the other hand, does not support the view that non-Acheulian or so-called "Pebble-Culture" or "Pre-Acheulian" occurrences of late lower and early mid-Pleistocene times represent a belated persistence of the African Oldowan. Non-handaxe assemblages may be directly related to similar repertoires found recently in Central Asia, as well as with the Chopper-Chopping Tool Complex of East Asia. The latter is now interpreted as a modification of the Acheulian, when ancient hominids adapted to circumstances of the tropical forest mosaic in Southeast Asia, by abandoning handaxe and cleaver manufacture. This simplified version of the Acheulian persisted, nevertheless, when the cool temperate latitudes of eastern China were colonized, due to geographical isolation. Similar isolation processes may have operated when the arid, continental zones of Central Asia were reached, as well as in the case of Europe.

We identify three alternative dispersal routes from Africa into Europe: indirectly through the Levant corridor and Anatolia into Southeastern Europe; directly across the Mediterranean straits, mainly Gibraltar; a protracted, indirect route, in three stages, each illustrating how ancient humans gradually adapted to temperate latitudes and wound around Eurasia's main topographic barriers. First, from Africa through the subtropical and tropical zones of Eurasia into China, secondly from the latter into Central Asia, and thirdly into Europe through a narrow corridor along the southern margin of the Palaearctic region, reaching Southeastern Europe through the northern Iranian plateau, the Transcaucasus and northern Anatolia. There are no conclusive proofs for any of these alternatives but the last working hypothesis receives stronger support from a combination of archaeological, biogeographic and geochronological evidence: a string of non-handaxe Lower Palaeolithic occurrences fits geographically and coincides in time with the end-Villafranchian and Galerian dispersal event into Europe, an event originating also in Central Asia.

\section{AFRICAN ANTHROPOGENESIS}

Any meaningful discussion of hominid expansion routes into Europe must begin with ascertaining where hominization happened. Opinion since Darwin and Wallace has focussed on the Old World tropics i.e. Africa and Asia, because these regions were major evolutionary centres for mammals and hominoid primates and as supplies of emigrant species (Bigalke, 1968; Cooke, 1968; Teilhard de Chardin, 1956). The weight of evidence from evolutionary systematics, molecular genetics, palaeontology and primatology favours Africa over tropical Asia (Andrews and Cronin, 1982; Ciochon, 1983; Pilbeam et al, 1977; Pope and Cronin, 1984), a verdict which the palaeoanthropological, archaeological and geochronological records (2) from Africa make compelling (Coppens et al., 1976; Gable, 1980).

(2) Reports of artifacts from the Riwat are, Pakistan (Dennell et al, 1988) show commendable details and critical evaluations but their identity and age $(2.0 \mathrm{my})$ remain controversial.

T. P., 1992, ne 49 
Fossil hominids reach back to the Pliocene, nearly $4.0 \mathrm{my}$ at the latest. They show the presence of several hominid lines: genus Australopithecus, beginning with A. afarensis and its robustus and africanus successors; genus Homo with $H$. habilis evolving into erectus by about 1.6 my. Only $H$. erectus expanded beyond Africa.

The oldest archaeological traces in East Africa may be as early as 2.6 my (Hadar, in the Afar, Ethiopia), more definitely by 2.3 my (Omo valley, Ethiopia) or 1.96 my (Koobi Fora, Lake Turkana, Kenya) (Clark, 1976; Harris, 1986; Howell, et al., 1987; Roche and Tiercelin, 1987). The first repertoire is the Oldowan or technological mode 1 (Clark, 1977: table 5; Toth, 1985). It is followed in a linear development by the Acheulian technocomplex or mode 2, by about 1.5 my (Olduvai Gorge, upper Bed II, Peninj, Isaac and Curtis, 1974). Specialists now regard the "Developed Oldowan" as a technological or ecological facies or "type B", of the Acheulian (Gowlett, 1988; Isaac, 1974: 512; Stiles, 1979).

The sequential order of these two Lower Palaeolithic horizons in Subsaharan Africa, as successive technological developments, has important implications for discussions on the peopling of Eurasia: a) both originated in Africa prior to hominid dispersal; b) the Subsaharan African Acheulian itself precedes by a substantial amount of time any similar occurrences in North Africa and Eurasia. In the case of Europe, this may be by a coefficient of three (Alimen, 1977; Isaac, 1978). Given that the earliest known archaeological traces for a human presence beyond Africa cannot be much older than 1.25 my e.g. the Acheulian site of 'Ubeidiya, in Israel, as a datum line, any claims for nonhandaxes or so-called "Pebble-Culture" in Eurasia requires conclusive proofs and a coherent explanation.

Acheulian assemblages display considerable internal variability. Careful consideration must therefore be given to possibilities of sampling problems, before making a diagnosis. Consequently, the null hypothesis is that the Lower Palaeolithic repertoire possessed by the early hominids who colonized Eurasia was the Acheulian.

If Subsaharan Africa was the cradle of mankind, it is also there that the basic biocultural parameters that made hominid dispersal beyond that continent possible, such as bipedalism, toolmaking skills and a meat-eating propensity involving procurement strategies, were also developed (Bartholomew and Birdsell, 1957; Bunn, 1981; Gable, 1980). Issues about the respective roles of predation and scavenging are still debated (Binford, 1981; Bunn and Kroll, 1987; Blumenschine, 1987; Potts, 1984; Shipman, 1986) but there is no doubt that ancient hominids integrated early within a complex web of more or less competitive or cooperative relationships with other carnivore species.

The palaeontological record points to a major faunal transformation at the beginning of the lower Pleistocene in Subsaharan Africa, by $1.6 \mathrm{my}$, with the appearance of modern elements (Maglio, 1975: 461-462, 1978: 612; Martin, 1986: 380) and the local replacement of archaic carnivores e.g. sabertooth cats, by species with more developed social capabilities e.g. spotted hyena, lion, leopard, cheetah (Turner, 1982: 234-245, 1985), a behavioural trait also found in hominids, and correlated with larger brains (Hemmer, 1982). Until this early Pleistocene turnover, hominids $(H$. habilis) had achieved a symbiotic scavenging relationship with sabertooth cats, in a closed habitat community (Marean, 1989). The turnover coincides with the onset of drier conditions and more open habitats (Kappelman, 1984; Bonnefille, 1979). Hominids (H. erectus stage) then became involved in confrontational relationships with other carnivores. Their success in this modified relationship would apparently rank them high in the competitive hierarchy (Eaton, 1979: 16).

Turner $(1982,1985)$ argues that these hominid/carnivores interactive networks constituted one major initial condition for their simultaneous expansion into Eurasia. 


\section{THE HOMINID COLONIZATION OF EURASIA}

\section{Significance}

Of all the hominid prehistoric colonization events -others being the peopling of Australasia, of the Americas and of the Pacific islands - that of Eurasia was the most decisive and involved major adaptive demands (Clermont and Smith, 1980; Bordes and Thibault, 1977; Collins, 1976; Dennell, 1983: 37-39; Foley, 1987: ch. 10; Campbell, 1972; Perlès, 1987; Weiner, 1971).

1) expansion beyond African boundaries to incorporate gradually all of Eurasia more than doubled the realm already occupied by a single primate species. Subcontinental regions such as Europe, India, Southeast Asia or China may all fit within the African continent (Clark, 1981: fig. 4) but the latter fits easily inside Eurasia;

2) moving from a tropical continent into a bioclimatically varied one required coping with increasingly unfamiliar conditions, as hominids began to settle middle and higher latitudes. The initial colonization of subtropical portions of the Palaearctic region and of the Oriental region tropics provided habitat continuity. Moving northwards into temperate Palaearctic zones, however, meant coming to terms with "time stressors" (Torrence, 1983) such as sharply defined seasonal contrasts with long winters, protracted dark nights, reduced food biomass, at the same time as meeting higher calorie requirements. The basic physiological adaptations of ancient hominids in the tropics (Montagu, 1964) did not predispose them for such a transition.

Nevertheless, their descendants were already leaving traces of their presence in mid-latitudes, from the North European plain to Korea by 200-300 ky. Their success in achieving this resulted from combining physiological, behavioural and technological traits. Artificial means, gradually mastered until post-Pleistocene times, included fire-making tecniques, clothing, constructed shelters, animal traction or snowshoes for transportation and specialized toolkits and weaponry;

3) this ongoins dispersal throughout huge areas during the Pleistocene, however, did not lead to speciation or adaptive radiation. This is due to one basic factor, shared with other larger carnivores, namely eurytopic and exogenous capabilities, with reliance on a carnivorous diet, enabling widespread geographical expansion without profound genotypic modifications or ecological specializations (Foley, 1987: 263-267). Several other African carnivore species (lion, leopard, spotted hyena) succeeded in dispersing throughout Eurasia but unlike hominids who consolidated their conquests of new environments, their realms were drastically reduced or they retreated into Africa after the Pleistocene;

4) an alternative consequence of expanding ranges and territories by hominids was that technoeconomic and social repertoires diversified and became more elaborate over time. This increasing scope for ethnic and cultural differentiation is shown by archaeological and ethnological evidence (Braidwood, 1960: fig. 1; Lévi-Strauss, 1958: 10) while peripheral gene flow maintained the human species' essential biological homogeneity.

\section{The initial hominid dispersal into Eurasia}

The scenario outlined by Howell (1960: 225) for earliest hominid movements beyond Africa remains essentially plausible, though still largely circumstantial and supported by only scant direct evidence. It involved first the Levant, with the Acheulian of 'Ubeidiya, datable to $1.25 \mathrm{my}$ (Techernov, 1987, 1988), followed by expansion along lowland and less arid areas of Southwest Asia such as the Mediterranean zone, extending then further inland prior to mid-Pleistocene tectonic upheavals (Horowith, 1979: ch. 3), the rim of the Fertile Crescent with the Assyrian steppe, the Mesopotamian lowlands (much more extensive during glacio-eustatic episodes) and perhaps, the lowermost portions of the outer Taurus and Zagros piedmonts. This would then lead to movements along the southern 
edge of the Iranian plateau and its mountain barriers, although direct evidence for this again is absent, scarce and mostly undated (Singer and Wymer, 1978: 24; Smith, 1986: 16).

Evidence becomes abundant upon reaching the Indian subcontinent and roughly datable to midPleistocene times, from associated faunal remains. All of it is Acheulian, often accompanied by numerous pebble-tools. Older evidence is either eroded away or deeply buried (Misra, 1989). It should be mentioned that the subcontinent was not part of the Oriental faunal region during the Pleistocene. Its fauna was highly endemic, with added Palaearctic elements (Kretzoi, 1961-64; Azzaroli, 1986).

With Southeast Asia and the Oriental faunal region, we encounter a distinct Lower Palaeolithic repertoire, associated with Homo erectus remains in Java and China, defined and labelled the "Chopper-Chopping Tool Complex" by Movius $(1944,1948)$ for the entire Far East. Many have criticized some of Movius' conclusions (amorphous artifactual assemblages, technological stagnation) and terminology and even questioned its reality (Freeman, 1977; Boriskovskii, 1978; Chung, 1976, 1984; Yi and Clark, 1983), partly owing to new discoveries of Acheulian-like implements such as handaxes and cleavers in China, Java and Korea. Movius failed to identify a cause for the origins of this East Asian Lower Palaeolithic complex (1978).

The reality of a Lower Palaeolithic repertoire dichotomy comprising a "western" handaxe and cleaver technocomplex (Acheulian) and the non-handaxe East Asian complex as an issue, has considerable bearing on the problem of the peopling of Eurasia. A. Sieveking (1962) proposed an explanation, when reporting on the Kota Tampan site in Malaya: the East Asian non-handaxe complex, renamed the "Pebble and Flake" tradition, was the outcome of a rapid and widespread initial hominid dispersal from Africa into Asia, who manufactured an unspecialized "Pebble-Culture" industry, derived from the Oldowan, which could diffuse into varied environments, during the late lower Pleistocene. Conditions in the Indo-Malaysian tropical forests of Southeast Asia favoured simple technologies, and inhibited the subsequent spread of the more specialized Acheulian, developed under conditions of savanna or savanna-open woodlands. This interpretation has become redundant due partly to the unsatisfactory Kota Tampan evidence and superseded by other interpretations.

Sufficient reasons remain, nevertheless, to retain the notion of a separate Lower Palaeolithic repertoire in East Asia (Ikawa-Smith, 1978; Aigner, 1978; Ayres and Rhee, 1984): new and dated discoveries in Java, Thailand and China; the inconclusive nature of so-called handaxe and cleaver finds in these regions. Most are atypical, very low in relative or absolute frequencies (this writer's data show that several single Acheulian sites in Western Europe or Africa contain more handaxes and cleavers than the entire collections from East Asia). Their dating is upper Pleistocene times, suggesting a self-contained development.

The most reasonable explanation for the appearance of this East Asian non-handaxe complex is that it represents an adaptive modification of the Acheulian when hominids colonized the dense Indo-Malaysian tropical forests of Southeast Asia. This induced a shift towards greater dependence on plant foods, solitary or smaller game (Watanbe, 1985) and widespread exploitation of bamboo as an all-purpose raw material, requiring nothing more than a rudimentary lithic toolkit, in environments where supplies of cryptocristaline rocks are scarce (Hayden, 1978; Hutterer, 1978; Pope, 1984, 1988; Solheim, 1970).

This modified repertoire, involving the abandonment of handaxe and cleaver manufacture, persisted when the subtropical and cool temperate latitudes of China became settled, although the need for an expanded lithic equipment was resumed. This was due to geographic isolation and long distances from the nearest area of handaxe/cleaver manufacture i.e. India, as well as continuing bamboo availability. Fossil and archaeological evidence for hominid presence in East Asia reaches back to over 1.0 my (Pope et al., 1987). In China, archaeological occurrences of lower Pleistocene age with local Villafranchian faunal associations include Xihoudou (Lanpo, 1980), Dunggutuo and Xiaochangliang, in the Nihewan basin (Lanpo and Qi, 1987; Qi, 1988), all without handaxes or cleavers but some with heavy duty or large cutting tool equipment, as well as finely made flake implements. 


\section{THE PEOPLING OF EUROPE: REVIEW OF HYPOTHESES}

\section{Obstacles to direct or early movements into Europe:}

Conditions for penetrating Europe during the Lower Palaeolithic were less favourable because more contingent on geographic factors than later on, more rudimentary technological means, and lower hominid population densities restricting habitat diversity and home ranges. Cyclical glacial episodes amplified or modified environmental barriers constraints. These include:

1) physical barriers such as a) major high mountains and plateaus ranges, stretching West to East across Eurasia, with the Taurus, Zagros, Armenian Knot, the Caucasus, Elburz, Kopet Dagh and especially, further East, the massive system linking more or less continuously the Paromisus, Hindu Kush, Pamirs, Karakorum, Tien Shan, Hymalaya, Kunlun, Altyn Tagh, Nan Shan and Qinling ranges. While not all entirely impenetrable, they inhibited early humans and their limited expansion means; b) aquatic barriers, with the Mediterranean in the West. Glacio-eustatic sea level fluctuations could improve direct crossing conditions from Africa into Europe, or around the Black Sea and across the Bosphorous (Chepalyga, 1984) but the Caspian Sea expanded considerably to the North, narrowing passage areas already reduced by glacial lake barriers in Western Siberia (Alekseev et al, 1984: map 3);

2) climatic barriers relating to extended permafrost zones, modified colder air circulation patterns (Velichko, 1984: figs. 25.10, 25.15) during ice ages, constituted significant limitations for a tropical species. The $10^{\circ}$ isothern of the coldest month of the year always remained a major impediment to human movements (Whiting et al., 1982);

3) ecological barriers, as hominids moved North of the $30-40^{\circ}$ latitude in Eurasia, encountering cold boreal forests and steppes, taiga and cold deserts from West to East, and loess deposition belts restricting vegetation growth during glacials. The archaeological record shows that prehistoric communities coped with such unfamiliar and unattractive conditions gradually, e.g. the Middle Palaeolithic for steppic continental environments in Central Europe (Bosinski, 1982), the Siberian taiga during the Holocene.

\section{Emigration routes into Europe}

Europe could be reached 1) directly from the Maghreb through Gibraltar or across the strait separating Tunisia from Sicily. Sea level regressions may have created narrow landbridge strips or reduced water barriers (channels). Alternatively, crossings may have been achieved at any time through artificial means (Alimen, 1975; Bordes and Thibault, 1977; Chard, 1963); 2) indirectly, through the Levant and into Anatolia and Southeastern Europe. The Taurus/Zagros/Armenian Knot, however, presented topographic and bioclimatic barriers for movements beyond which were overcome only later (Howell, 1960). Movements from the East, across the Kazakh and Russian steppes would imply a more precocious adaptation to cold, continental steppes than is evidenced directly. We shall examine, further on, another possibility from the East, with a route from Central Asia through a filter corridor along the northern edge of the Iranian plateau, the Transcaucasus and northern Anatolia or, perhaps, the presently submerged northern rim of the Black Sea.

In summary, despite Europe's proximity to Africa, ancient hominids could have encountered difficulties in expanding there, whatever the route taken.

\section{Age of earliest anthropic evidence in Europe}

Viewpoints concerning human antiquity in Europe have varied and have opposed proponents of short and long chronologies. By the early 1960s, after the "eoliths" controversy and the Piltdown 
forgery had been settled, it was considered that a Mindel/Elster date was probably the oldest limit, based on the Abbeville (Porte du Bois) archaeological finds and the Mauer mandible (Howell, 1960). By 1966, new evidence (Vallonet cave, L'Escale, Ferme de Grâce) required pushing this boundary further back i.e. Günz (Howell, 1966: 177-178; Bordes, 1968: 48-49). Other archaeological finds included the Chilhac finds, whose $1.7 \mathrm{my}$ estimated date and provenience were controversial. Recent claims for anthropic occurrences of Pliocene age from the Massif Central (Bonifay, 1989; Bonifay et al., 1989) have been received skeptically (Delson, 1989; Lumley et al, 1988: 591-596). The equally controversial cranium from Orce, Venta Micena, claimed to be hominid (Agustí et al., 1983) also appears questionable (Moyá Solá and Agustí, 1990).

Despite conflicting claims or taphonomic arguments suggesting that the scarcity of anthropic finds in Europe is more apparent than real and has more to do with evidence loss than with later peopling (Dennell, 1983: 35-37; Bordes, 1968: 49-50), steadily increasing discoveries and better chronological resolution indicate an age around $0.90 \mathrm{my}$ for earliest humans in Europe.

\section{Identity of the earliest Palaeolithic in Europe}

Aside from earlier erroneous acceptance the "eoliths" or the "Cromerian industry", the oldest artifactual evidence recognized for a long time in Europe were handaxe assemblages known since John Frere's and Boucher de Perthes' discoveries. The handaxe horizon from Porte du Bois at Abbeville, constituted a datum line. The early authors' linear succession of handaxe stages was replaced by Breuil's (1932) parallel phylla of handaxe (Abbevillian, Acheulian) and non-handaxe (Clactonian, Levalloisian, Tayacian) industries. This was superseded, in turn, by a complex "évolution buissonnanten model (Bordes, 1950a). Nevertheless, the notion of separate, more or less coexisting Lower Palaeolithic industry types has been retained by many until now (Bordes, 1968: ch. 7; Collins, 1969; Howell, 1966: 179-180; Kretzoi and Vértes, 1965; Roe, 1981), largely to incorporate the Clactonian and continental non-handaxe occurrences of different ages (Vallonet, Monte Peglia, Vértesszollös).

While there is growing acceptance that most of the earliest archaeological traces in Europe appear to be non-handaxe occurrences (Bordes and Thibault, 1977; Lumley et al, 1988; Piperno et al, 1983), there is surprisingly little discussion about the implications of chronological overlap between handaxe and non-handaxe industries (see Collins, 1969 and comments). Issues include discriminating between environmental and behavioural (function, tradition) factors possibly involved and the origins of non-handaxe repertoires.

The dominant view has been to regard older non-handaxe industries as part of an archaic and widespread "Pebble-Culture" horizon throughout Eurasia, derived directly from the Oldowan (Bordes, 1968: 134; Bordaz, 1970: 18-20; Howell, 1966: 178; Kretzoi and Vértes, 1965; Rolland, 1977: 134; Sieveking, 1962). We shall review reasons why this needs revision. The question of discontinuous non-handaxe repertoires in different parts of Eurasia, establishing their chronological positions, are part of evidence and issues to be considered when assessing the origins and dispersal routes followed by hominids into Europe.

\section{Was the colonization of Europe a separate event?}

Howell or Sieveking treated the peopling of Europe as a later event, because of environmental barriers. There has been since a tendency to lump it as part of the synchronous colonization of Eurasia, around $0.7 \mathrm{my}$ or Brunhes/Matuyama geomagnetic boundary, proposed as a lower/middle Pleistocene boundary (Isaac, 1974: 512, 1978) , a datum line retained by Turner (1982: table 2) when suggesting a simultaneous dispersal of hominids and African carnivores into Europe.

Chronological evidence for the peopling of subtropical and tropical Asia and temperate China

T. P., 1992, n² 49 
indicate, however, that this 0.7 my date for the initial human dispersal out of Africa is too recent. Combining these new dates over $1.0 \mathrm{my}$ with the earliest acceptable dates for Europe, it is concluded that both colonization events were allochronous, with problems deserving separate consideration.

\section{APPROACHES UTILIZED}

\section{Difficulties of synthesis}

Reasons for a virtual lack of extensive, in-depth, and up to date syntheses about Lower Palaeolithic peopling of Europe include

1) its multidisciplinary scope which means keeping abreast of developments in a range of disciplines, particularly palaeoanthropology, Palaeolithic archaeology and Quaternary research. It also involves gathering, sifting and evaluating a voluminous body of publications (journal papers, reports, chapters and monographs) in several languages, often difficult of access,

2) the fact that this published information constitutes only a portion of a larger body of research results, reaching professionals with a time lag. New empirical findings or new conceptual developments may also lead to complete revisions of accepted conclusions. Synthesis requires firsthand acquaintance with much of this primary evidence, published or not, to evaluate it critically,

3) most of the archaeological information is the outcome of field researches designed with other objectives in mind. The considerable demands of work and time that fieldwork involves leave principal investigators with little additional time for large-scale syntheses. Few projects are explicitly devoted to the present topic, in strategically-defined regions,

4) difficult resolution in topics relating to earlier Pleistocene and Palaeolithic horizons. Major information gaps persist concerning the archaeological record, chronology and regional coverages, despite a growing volume and quality of primary evidence. Generalizations remain provisional, leaving many questions unanswered.

\section{Lines of evidence}

The topic requires considering a wide array of evidence: anthropic (fossil hominid remains, Palaeolithic sites and remains), palaeobiological (animal palaeontology, palaeoecology), Quaternary research, and geochronological. The most crucial for our purpose relate to biogeography and Lower Palaeolithic repertoires, followed by palaeogeography and geochronology.

Biogeography. Historical biogeography or the study of dispersal events involving land mammals (Simpson and Beck, 1965: ch. 28) is especially relevant. Population movements of this kind are distinct from migration i.e. cyclical or seasonal and regulated movements within home ranges (1965: 733, Rouse, 1986: 9). Colonization is a kind of emigration or less regulated movement, with expansion into ranges hitherto devoid of members of the same species, and adaptive processes, over several generations. Causes such as demographic pressure or environmental change apply to human movements as well (Darlington, 1957: 621-646; Lack, 1970: 242-243).

The late lower Pleistocene colonization of Europe by one primate species emigrating from the Ethiopian into the Palaearctic region was an event which could be studied as part of a larger process including other animal species as prey or as competitors (Turner, 1982).

Biogeographers classify dispersal routes or "dispersal probabilities" as follows (Simpson, 1940, 1962; Simpson and Beck, 1965): a) corridors where chances for large-scale spread-are high, such as the Eurasian corridor within the Palaearctic region, connecting Europe with China, or the Levant corridor between the Levant and Africa; b) filters allowing the spread between regions or continents 
of only certain species or populations because of barriers' selective effects e.g. the episodic crossings of the Sahara, along narrow stretches of oasis areas, during wetter palaeoclimatic phases, c) sweepstake routes where crossings occur during brief periods of opportunity and are very improbable for most elements because of effective barriers such as channels, straits, sea barriers. Only single emigrant groups succeed e.g. the hominid peopling of Australasia during the upper Pleistocene or perhaps, the crossing of Gibraltar at an earlier time.

Late Cenozoic mammalian dispersal events. Palaeontologists have identified several Plio-Pleistocene events for the Holoarctic regions (Repenning, 1967; Lindsay et al., 1980). Major faunal turnovers such as during the early Pleistocene in Africa or late lower Pleistocene in Eurasia (Maglio, 1975) could have been related with early hominid dispersals.

\title{
Linkages with hominid colonization events
}

We summarized earlier Turner's hypothesis about such connections with respect to emigrations out of Africa. Dispersal events identified for the Plio-Pleistocene in Europe are summarized in table 1. The most significant, as well as relevant to the Lower Palaeolithic peopling of Europe, is the end-Villafranchian/Galerian dispersal event (Guthrie, 1984) during later lower Pleistocene times. No attempts have been made so far to connect the initial hominid expansion into Europe with this event originating in Central Asia -although M. F. Bonifay (1983: 2) notes a significant hominid presence then.

The end-Villafranchian/Galerian dispersal event. Palaeontologists have observed this event in Western Europe (Bonifay, 1978, 1979, 1980, 1983; Azzaroli, 1983) but it has been noted nearer its point of origin (Azzaroli and Napoleone, 1982; Azzaroli et al. 1988). It was marked by profound modifications of Palaearctic large mammals, with massive extinctions of Villafranchian elements or their rapid local evolution, new arrivals with a trend toward gigantism: diversification of large bovids (Bison, Bos, Ovibos, Bubalus), of cervids developing huge, elaborate antlers (Megaceros, Cervalces, Rangifer), bears (Ursus spelaeus) and rhinoceroses (D. hemitoechus, D. merckii, Elasmotherium. These often paedogenic adaptive traits are diagnostic of pioneering or colonizing species (Geist, 1971).

Most pre-existing Eurasian carnivores (Homotherium, Magantereon, Felix toscana, Hyaena brevirostris) were gradually replaced by incoming more social African carnivores and the wolf, from the Near East. The cave lion of Europe assumed giant proportions (Kurtén, 1968).

This major faunal transformation happened rapidly, coinciding in time with the Jaramillo normal event, between 1.0 and 0.9 my and into the late Matuyama reversed epoch (Azzaroli, 1983). It began in Central Asia and spread throughout the Palaearctic region. Villafranchian holdovers lingered longer in Western Europe. Its causes are not related to connections by intercontinental landbridges but with protracted environmental changes, beginning with major tectonic upheavals in Central and South Asia (Azzaroli, 1983: 135; Azzaroli and Napoleone, 1982), then with significant marine and continental climatic shifts, reflected in changes of atmospheric circulation patterns and more seasonal vegetation patterns.

Lower Palaeolithic repertoires. Subsuming Palaeolithic archaeology within palaeontology (Turner, 1982: 236) would add a new, meaningful dimension of hominid behaviour studies but entails the risk, if carried out unilaterally, of blurring specific and significant information contents within toolmaking repertoires which may provide evidence no less decisive than socio-ecological insights about issues such as dispersal routes. The artifactual composition and time-space distributions of Lower Palaeolithic complexes vary non-randomly. It would be shortsighted to ignore this. These inter-assemblage variations can be sorted descriptively under two major assemblage types:

1) handaxe/cleavers assemblage type. These all refer to the Acheulian technocomplex. The

\author{
T. P., 1992, $\mathrm{n}^{2} 49$
}


TABLE 1. Late Pliocene-lower Pleistocene faunal dispersal events in Europe (after Azzaroli, 1983; Azzaroli, et al. 1988, Bonifay 1979, 1980, 1983)

\begin{tabular}{|c|c|c|c|c|c|}
\hline $\begin{array}{l}\text { FAUNAL } \\
\text { SPANS }\end{array}$ & $\begin{array}{c}\text { MAMMAL } \\
\text { DISPERSAL EVENTS }\end{array}$ & $\begin{array}{l}\text { AGE } \\
\text { MY }\end{array}$ & DIAGNOSTIC ELEMENTS & KEY LOCALITIES & $\begin{array}{c}\text { PALEOCLIMATES, } \\
\text { PALAEOENVIRONMENTS }\end{array}$ \\
\hline $\begin{array}{l}\mathrm{Q} \\
\mathrm{U} \\
\mathrm{A} \\
\mathrm{T} \\
\mathrm{E} \\
\mathrm{R} \\
\mathrm{N} \\
\mathrm{A} \\
\mathrm{R} \\
\mathrm{Y}\end{array}$ & $\begin{array}{l}\text { «End-Villafranchian/ } \\
\text { Galerian» }\end{array}$ & 0,97 & $\begin{array}{l}\text { Bison schoentensacki, Praeovibos } \\
\text { cervalces latifrons, Megaceros, } \\
\text { Rangifer, Elephas antiquus, Equus } \\
\text { sussenbornensis, Dicerorhinus } \\
\text { hemitoechus, Crocuta crocuta, } \\
\text { Panthera leo, Panthera pardus, } \\
\text { acinonyx jubatus }\end{array}$ & $\begin{array}{l}\text { L'Escale, Mosbach, Cúllar-Baza I, } \\
\text { Voigstedt, Stránská Skála, } \\
\text { La Pineta, Soleihac, Monte } \\
\text { Peglia, Vallonet, Domegliara }\end{array}$ & $\begin{array}{l}\text { Europe: interglacial; Central } \\
\text { Asia; cold, tectonics; massive } \\
\text { faunal turnover }\end{array}$ \\
\hline $\begin{array}{l}\text { V } \\
\text { I } \\
\text { L } \\
\text { L }\end{array}$ & «Wolf» & 1,7 & $\begin{array}{l}\text { Canis etruscus, Crocuta brevirostris, } \\
\text { Panthera toscana, Archidiskodon } \\
\text { meridionalis, Leptobos etruscus }\end{array}$ & Olivola, Le Coupet, Chilhac & $\begin{array}{l}\text { Eburonian; temperate, cooler, } \\
\text { prairie faune }\end{array}$ \\
\hline $\begin{array}{l}A \\
F \\
R \\
A \\
N\end{array}$ & «Elephas/Equus» & 2,5 & $\begin{array}{l}\text { Archidiskodon gromovi, } \\
\text { Gazella borbonica } \\
\text { Equus livenzovensis }\end{array}$ & Rincon I, MontoPoli, Roca Neyra & $\begin{array}{l}\text { Pretiglian: typical forest } \\
\text { elements disappear; open } \\
\text { parkland, savanna grassland }\end{array}$ \\
\hline $\begin{array}{l}\text { C } \\
\text { H } \\
\text { I } \\
\text { A } \\
\text { N }\end{array}$ & «Leptobos» & 3,2 & $\begin{array}{l}\text { Leptobos, Cervus pardinensis } \\
\text { Anancus arvernensis, Tapirus, } \\
\text { Megantereon, Homotherium }\end{array}$ & $\begin{array}{l}\text { Perrier-Etouaires, Vialette, } \\
\text { Triversa, Villaroya, Villafranca }\end{array}$ & $\begin{array}{l}\text { Reuverian; warm/temperate, } \\
\text { wet; more open forest }\end{array}$ \\
\hline
\end{tabular}


nomenclature has been simplified. It is found throughout Africa, Western Eurasia and the Indian subcontinent. Its most specialized and diagnostic elements are the large cutting tools known as handaxes and cleavers but Acheulian assemblages display a marked degree of polythetic variability in terms of modal frequencies, ranges and dominance patterns, not confined to large cutting tools and applying to other implement forms such as pebble-tools, scrapers, denticulates, notches. The term "Abbevillian", while still used, should be abandoned. Its distinctiveness has been overstated. The label has connotations of an archaic handaxe manufacture stage, at variance with its contents. It is comparatively late, when compared with the Acheulian in Africa.

2) non-handaxe assemblage types. Their apparent simplicity results more from generalized and technologically restricted characteristics. These assemblages constitute a heterogenous group, rather than a single complex such as the so-called "Pebble-Culture». Terminologies also remain unsatisfactory. They include the Oldowan, the "Pebble-Culture" of North Africa, the non-handaxe Lower Palaeolithic of Central Asia, the «Pre-Acheulian» of Europe and the Chopper-Chopping Tool complex of East Asia.

The Oldowan is better defined. The "Pebble-Culture" (Biberson, 1961b) would be a parallel or phyletically related to it but its reality is now in doubt. The East Asian Complex, originally thought .to be derived from the Oldowan, is better seen as a permanently modified version - but not a facies or atypical variant - of the Acheulian. Both non-handaxe assemblage types from Central Asia and Europe require an interpretation and appropriate nomenclatures. The Clactonian and other later mid-Pleistocene industries of Europe are left out. Their age makes them less relevant to questions relating to the peopling of Europe.

Geochronology. It remains essential to have a degree of control over the time coordinate, to establish the relative anteriority, posteriority or penecontemporaneity between Lower Palaeolithic complexes, mammalian dispersal events, as well as palaeoclimatic and palaeogeographic circumstances. Precision with respect to earlier Pleistocene horizons remains unavoidably broad. It could not allow detailed plottings of time-space distributions documenting exactly dispersion rates of human or mammal species, as for instance with the spread of Neolithic economies into Europe. At any event, certain expansion events were so rapid that they would escape detection on a geological time-scale, e.g. at rates of $1000 \mathrm{~km}$ per century (Kurtén, 1957).

Nevertheless, considerable progress has been achieved in chronostratigraphic and chronometric age determination methods and long-distance correlations (e.g. Bonifay, 1980; Kukla, 1978, 1987): geomagnetism, tephrochronology, biostratigraphy and biozonation, loess cycles, marine isotope chronology, as well as $\mathrm{K} / \mathrm{Ar}$, fission track and TL dating.

Palaeogeography. These have already been mentioned: topographic and water barriers; latitudinal and ecological barriers; palaeoclimatic changes influencing positively or restricting animal or human movements. These factors would also interplay in a complex fashion with ancient hominid demographic parameters (local group or regional densities, reproductive networks) (see Dennell, 1983: 37 38; Wobst, 1976). Unfortunately, it is difficult to make these important processes operational.

\section{THE EARLIEST LOWER PALAEOLITHIC HORIZON IN EUROPE}

After outlining main sources of evidence, we survey the anthropic record for the initial occupation horizon of Europe i.e. a time-span from late lower to early mid-Pleistocene times or 0.90 to $0.55 \mathrm{my}$, to establish its characteristics and patterns, and whether it contains archaeological indications about the origins and directions of hominid movement into Europe. One issue is whether this early Lower Palaeolithic horizon is a handaxe (or Acheulian) or non-handaxe repertoire and what are the implications of this diagnosis. 


\section{General conditions}

1) the quality of this evidence varies in terms of sampling sizes, dating precision and associated remains. The list of 68 occurrences (66 archaeological) ranges from findspots with single or few artifacts to rich collections in primary archaeological contexts. Some may find the coverage too generous; others, too restrictive. Virtually all occurrences, however, meet minimum requirements of provenience control within a broad geological framework, artifact identification and chronology, and exclude controversial finds e.g. Massif Central, Venta Micena, Rumania and Macedonia;

2) a large portion of the sites listed were from chance or incidental discoveries, or during geological or palaeontological investigations, without further fieldwork. Much of the information remains therefore provisional. Nevertheless, this evidence is largely new and in need of synthesis. Systematic, archaeologically oriented excavations are increasing as discovery prospects are rewarded;

3 ) the paucity, variable quality and often rudimentary information content of early hominid traces in Europe has much to do with preservation or visibility conditions, which are less favourable in mid-latitudes, due to geomorphological changes related to glacial/interglacial cycles, as well as to the effects of millenia of intense agro-pastoralist exploitation, than in privileged regions such as East or Southern Africa (Bordes, 1968: 49-50; Dennell, 1983: 35, 37). Discoveries of the last 15-20 years, however, show that some evidence has survived and that certain regions' conditions approach those of Africa.

\section{Presentation of evidence}

A detailed discussion of the archaeological record is beyond this paper's scope. Coverage is limited to main features of the evidence, partly summarized in table 2, and identifying issues.

Literature. Much of the anthropic evidence listed in the Appendix is available in publications and summary syntheses on regional or continental scales (e.g. Bordes and Thibault, 1977; Broglio et al, 1982; Bonifay, 1981; Collins, 1986; Dreiman, 1983; Lumley, 1982; Lumley et al, 1988; Peretto and Piperno, 1985; Piperno, 1985; Ripoll Perelló, 1983; Santonja, 1976, 1981; Santonja and Querol, 1982; Santonja and Villa, 1990; Svoboda, 1980, 1984; Valoch, 1976, 1984 for major references). Literature citations will be restricted to essentials because of space constraints.

TABLE 2. European Early Palaeolithic Horizon; major information contents

\begin{tabular}{lr}
\hline \multicolumn{1}{c}{ ITEMS } & N. ocurrences \\
\hline Faunal association & 27 \\
Anthropogenic fauna & 6 \\
Sites in primary (archaeological) situation & 6 \\
DATING: 1 l. lithostratigraphic & 59 \\
2. biostratigraphic & 31 \\
3. litho-biostratigraphic & 28 \\
4. geomagnetic & 20 \\
5. radiometric & 21 \\
6. lithostratigraphic + geomagnetic & 6 \\
7. lithostratigraphic + geomagnetic + radiometric & 9 \\
8. litho-biostratigraphic + geomagnetic & 4 \\
9. litho-biostratigraphic + geomagnetic + radiometric & 8 \\
\hline
\end{tabular}


Major areas and localities. These refer to regions with proven and sometimes rich documentary materials, combining favourable conditions reminiscent of East Africa, such as tectonics (volcanics, faulting), fluvio-lacustrine, and additionally, loess deposition, as agencies for sealing anthropic or fossil remains and for developing radiometrically and geomagnetically dated stratified sequences:

1) Guádix-Baza depression, Betic region of Southeastern Spain. It contains some barely explored Plio-Pleistocene fossil localities e.g. Venta Micena (Agustí et al, 1983; Gibert Clols et al., 1989), CúllarBaza (Ruiz Bustos and Michaux, 1976; López Martinez and Ruiz Bustos, 1977). Only the latter has yielded (rare) artifacts older than the Acheulian i.e. Solana del Zamborino (Botella López, 1975a, b), Iznalloz. The Orce skull, Venta Micena, has not been accepted yet as human (Agusti and Moyá Solé, 1987). The region is strategically located with palaeolacustrine formations, and should reward intensive investigations.

2) Massif Central, France. This region, investigated since the last century, contains classic radiometrically and geomagnetically calibrated Plio-Pleistocene fossil localities (Bout, 1976; Bout and Viret, 1976; Biquand, 1987) because of its favourable taphonomic conditions. Several sites have been claimed as anthropic (Bonifay, 1981, 1989; Bonifay et al, 1989) Sainzelles, Ceyssaguet, La Rochelambert, St. Eble-Le Coupet, Les Etouaires, Senèze but as mentioned earlier, are generally not accepted. The earliest Palaeolithic site is Soleihac (Bonifay, 1980; Bonifay et al., 1976; Bonifay and Tiercelin, 1977) with in situ occupation, mammal fauna, dating to final Jaramillo normal event. Other early sites have less satisfactory provenience, faunal associations and dating e.g. Chilhac III (Guth, 1982) or Blassac-les-Battants. The region also contains evidence for the Acheulian (Pié du Roi, Ste. Anne, Senèze) and later Palaeolithic horizons.

High altitude and a continental climate made the Massif Central a region of only episodic Palaeolithic occupation which was probably marginal during the earlier Pleistocene. Discovery pace is slowed down by scarce exposures or stratigraphic "windows", due to a moist climate and lush vegetation.

3) Central and Southern Italy. This portion of the Italian peninsula, along the Apennine divide, is demonstrably the most prolific of all European regions for earlier Pleistocene anthropic documents. These are concentrated in the Latium (Anagni, Fontana Liri, Arce, Castro dei Volsci: Biddittu, 1972; Segre, 1984; Segre and Biddittu, 1981), Molise (Isernia La Pineta: Coltorti et al, 1982 a, b; Peretto et al, 1983; Cremaschi and Peretto, 1988), and Basilicata (Irsina, Venosa-Loreto: Segre, 1978, 1982; Baissas, 1980; Chiapella, 1964; Piperno and Segre, 1982). Favourable taphonomic circumstances are analogous to those of the Massif Central but with the benefit of erosional exposures. Early Lower Palaeolithic occurrences range from late Matuyama reversed $(0.85 \mathrm{my})$ to earlier Brunhes normal polarity (up to $\mathbf{0 . 6 0} \mathrm{my}$ ). This region contains also important early Acheulian sites e.g. Fontana Ranuccio, Venosá-Notarchirico.

4) Loess and fluvio-lacustrine deposits of Central Europe. This region encompasses Lower Austria (Krems locality), Bohemia and Moravia and is best known for radiometrically and geomagnetically dated master sequences of loess, palaeosols and glacio-fluvial complexes, some at the contact of Alpine and Fennoscandian glacial moraines and correlated with distant Eurasia sequences and marine isotopic stages (Fink and Kukla, 1977; Kukla, 1975, 1978, 1987). Archaeological evidence so far is limited in occurrences and artifact numbers but these provide important archaeological datum lines, sites of Č̉erveny kopec, Staré Město, Bečov, Suchdol, Stránská Skála (Chlachula, 1991, in press; Musil, 1976; Svoboda, 1980, 1984; Valoch, 1968, 1976, 1984).

This overview does not mean that other isolated but important localities have been overlooked. These are scattered throughout Europe: El Aculadero (Querol and Santonja, 1983a), near Cádiz, Vallonet cave, French Riviera (Lumley et al, 1988), Ca' Belvedere, Monte Poggiolo, in Emilia Romagna (Cremaschi and Peretto, 1988; Peretto et al., 1987), Visogliano, Trieste (Tozzi, 1978-81, 1987, 1990), Monte Peglia, Umbria (Piperno, 1972, 1989), the recently excavated Trzebnica, Poland (Burdukiewicz et al., 1988, 1990), Korolevo, Ukraine (Gladilin, 1989, 1990; Kulakovskaia, 1989), Yarım Burgaz, in Turkish Rumelia (Özdoǧan and Koyunlu, 1986; Farrand, 1989), Azykh cave, Azerbaidjan (Guseinov, 1974; Liubin, 1984, 1989).

T. P., 1992, n 49 
It is worth noting that sites are more numerous and often richer in the Mediterranean or temperate mid-latitude areas of Europe than further North, which may inform about ancient hominid adaptive capabilities.

Occurrences types. These illustrate varied situations with respect to geomorphological and settlement settings. Most are geologically but few archaeologically in situ e.g. Soleihac, La Pineta, Venosa-Loreto, Staré Mèsto. Cave occurrences represent brief halts, rather than living sites e.g. Cueva Victoria, Vallonet, L'Escale, Monte Peglia, Sandalja, Stránská Skála, Yarim Burgaz, Azykh. Geomorphological and mammalian composition mosaics indicate that fluvio-lacustrine or palaeolacustrine settings attracted ancient hominids e.g. Soleihac, La Pineta, Cúllar-Baza, Porte du Bois, Prezletice, Suchdol, Staré Mèsto, Castro dei Volsci, Fontana Liri, Venosa-Loreto. Beyond these observations, however, information concerning on-site and off-site evidence, settlement and activity patterns remains limited, given the taphonomic and retrieval conditions cited earlier.

Archaeological contents. Lithic artifacts constitute the most regularly available evidence. Artifact frequencies range from single or few pieces e.g. Irsina, Ferme de Grâce, Cúllar-Baza, Kărlich, Sandalja, to hundreds (La Pineta) or thousands (Venosa-Loreto, Ca' Belvedere). Many occurrences contain mammalian associations but few are conclusively anthropogenic. The same applies to artificial or activity structures e.g. at Soleihac, La Pineta, Venosa-Loreto.

\section{Lithic assemblage characteristics}

Study methods. No uniformally agreed methods or descriptive norms are available for the early Palaeolithic of Europe, although some degree of consensus exists. This is part of a wider problem concerning Lower Palaeolithic artifact studies, excluding analyses of more standardized implement forms such as handaxes or cleavers (Bordes, 1961; Isaac, 1977; Roe, 1964; Tixier, 1957). Pebble-tool categories of Africa (Ramendo, 1963) or Europe (Carbonell et al, 1984; Collina-Girard, 1978) are also better described. The main stumbling block concerns flake implements (Movius, 1949; Bordes, 1971; Isaac, 1977), because of low specification or attribute cohesion degrees. This "amorphousness", however, has been overstated (see Freeman, 1978 for Lower Palaeolithic China), and does not apply to the flint artifacts of Visogliano or Venosa-Loreto. Attribute analysis, e.g. the Buda industry analysis (Vertes, 1962), or lithic reduction sequence analysis, e.g. the study of the East African Oldowan (Toth, 1985), are future directions to follow. The best example in our site list is in the El Aculadero monograph (Querol and Santonja, 1983a).

Raw material properties. Their shapes, sizes or textures can be determinant, given the limited range of flaking techniques available during the Lower Palaeolithic. Raw material exploitation varied according to local circumstances, although there are few tabulated comparisons or sourcing studies: flint, shale, obsidian, quartzite, quartz, phtanite, andesite, basalt, gneiss, hornstone, limestone, lydite. Certain sites display considerable heterogeneity e.g. Korolevo, where black andesite was common (Adamenko et al., 1989: 18).

Local materials were usually exploited although flint (Soleihac), quartz or quartzite (Stráská Skála) could be imported. Flint quality could be good (La Pineta, Visogliano, Trzebnica) or poor (Ca' Belvedere). Quartz from volcanic regions i.e. Massif Central, could make artifact identification problematic. Less tractable materials such as lydite (Přezletice), hornstone (Stránská Skála) or limestone (Visogliano, Colle Marino, Fontana Liri), gave artifacts an amorphous appearance. Limestone flakes still retain recognizable flaking attributes (butts, points of impact, percussion bulb) but their porous texture made them liable to geochemical disintegration, unless buried by sediments (Colle Marino). This local material was frequently used for making pebble-tools.

Lithic reduction sequence. Most occurrences contain variable frequencies of artifact classes diagnostic of successive lithic reduction stages: manuports, nodules, roughouts, discards, flaking debris, waste flakes, preforms, shaped tools. Certain sites (El Aculadero, Pointe aux Oies, Bibbona, Néa Skála) contain mostly preliminary stages artifacts. 
Primary flaking is unspecialized, more or less exhaustive, with nodular pieces bearing unifacial or bifacial scar patterns. Small flakes were often obtained by shattering tabular flint and used the fragments as cores, at La Pineta. Flakes are usually thick, with plain butts and wide percussion angles, or otherwise cortical. Trimming is also unspecialized, applied unilaterally or multilaterally, less often bifacially. Working edges patterns show scraping/cutting, serrated or notched attributes. Flint assemblages from Visogliano or Venosa-Loreto, however, show greater standardization and, perhaps, resharpening.

Techno-typological categories. Recurrent artifact classes comprise thick "discoid" and "épannelés" core types, choppers, choppingtools, crude bifacial implements "proto-handaxe" (Soleihac), polyhedrals, notches, denticulates - some large (El Espinar) - scrapers becs and miscellaneous core or flake implements. La Pineta contains many small, rostro-carinated tools. The only locality to yield many recognizable handaxes remains Porte du Bois, at Abbeville.

Early Lower Palaeolithic assemblages of Europe show internal and inter-assemblage variability analogous to the polythetic patterns of non-handaxe/cleaver components of the Acheulian. Pebbletools often dominate but many assemblages show flake tools dominance (La Pineta, Visogliano, Venosa-Loreto, Trzebnica).

\section{Chronology}

A detailed discussion of the European early Palaeolithic chronology, while desirable, would exceed the paper's scope. We concentrate instead on summarizing the main findings.

Dating methods. Their diversity has been instrumental in resolving the time-placement of many sites but their availability remains contingent on local conditions. Chronometric or geomagnetic dating conflict occasionally with biostratigraphy. The latter has potential pitfalls (Cooke et al., 1982: 26-27; Maglio, 1976: 421-424). Common dating methods include: lithostratigraphy, particularly of fluvio-lacustrine, loessic and volcanic deposits, mammalism biochronology (biostratigraphy, biozonation e.g. Cordy, 1982; Guérin et al., 1983), geomagnetism and chronometric (K/Ar, TL, ESR) determinations. Archaeological dating would be premature and potentially circular.

Certain regions (Massif Central, Central and Southern Italy, parts of Central Europe) benefit from the converging contributions of several methods. Others depend on lithostratigraphy alone, such as the provisionally dated findspots from the Aquitaine. The Lower Palaeolithic sensu lato from the Spanish Meseta, on the other hand, retain the advantage of a broadly reliable relative chronology, based on careful, detailed reconstructions of terrace sequences, incorporating tectonic factors and avoiding palaeoclimatic presuppositions or correlations with the Alpine sequence (Delgado, 1977; Pérez González, 1983 a, b; Santonja and Villa, 1990). Several of the early non-handaxe occurrences come from higher (and older) terraces, while the Acheulian is found in younger ones.

Results. Table 3 lists the better dated occurrences within a broad time framework. Section A contains those dated with several methods, including age calibrations (radiometric and/or geomagnetic), whereas section B provides for time-placements with wider margins of imprecision. All fit within a timespan beginning from the Jaramillo normal polarity event (or $0.90 \mathrm{my}$ ), through late Matuyama reversed polarity and up to early Brunhes normal polarity epoch (until 0.60-0.55 my). We comment briefly on the most important results:

1) Vallonet cave. Dated by coastal lithostratigraphy, biostratigraphy (microtine and an endVillafranchian/early Galerian faunas), geomagnetism and ESR dating (Chaline, 1988; Lumley, 1976; Lumley et al., 1988; Yokoyama et al., 1988). This evidence places the artifact-bearing layers B, B2, C during late Jaramillo normal polarity event, around 0.89-0.91 my and correlated with lower biozone 20 (Guérin et al., 1983: table 1).

2) Soleihac. The anthropic layers (units B, C, D) belong to a fluvio-lacustrine series deposited during a normal polarity phase, initially placed at the beginning of the Brunhes epoch (Bout and Goer de Herne, 1976), but since found to be interpolated between the E and A reversed polarity 
TABLE 3. Chronological Summary of Archaic (Pre-Acheulian) Lower Palaeolithic Occurrences in Europe

\begin{tabular}{|c|c|c|c|c|}
\hline PLEISTOCENE & $\begin{array}{l}\text { GEOMAGNETIC } \\
\text { TIME SCALE }\end{array}$ & $\begin{array}{l}\text { AGE } \\
\text { MY }\end{array}$ & A (chronological resolution optimal) & $\begin{array}{c}\text { B (biostratigraphic and/or lithostratigraphic } \\
\text { only) }\end{array}$ \\
\hline $\begin{array}{l}\text { EARLY } \\
\text { MIDDLE } \\
\text {. }\end{array}$ & $\begin{array}{l}\text { EARLY BRUNHES EPOCH } \\
\text { (normal) }\end{array}$ & 0,73 & $\begin{array}{l}\text { Valchetta Cartoni, Kärlich Bb, } \\
\text { Prezletice, Venosa-Loreto }\end{array}$ & $\begin{array}{l}\text { Porte du Bois*, L'Escale, Haute Durance, } \\
\text { Cúllar-Baza I, Westbury-sub-Mendip, } \\
\text { Visogliano, Achenheim, } \\
\text { Hangenbieten, Becov I-B, Suchdol, Pribice, } \\
\text { Mauer, Trzebnica, Yarim Burgaz }\end{array}$ \\
\hline \multirow{2}{*}{ 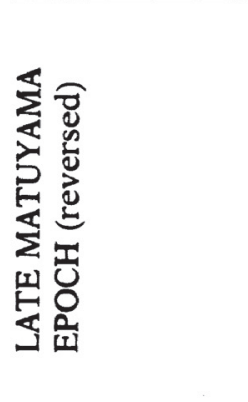 } & LATE MATUYAMA & 0,90 & $\begin{array}{l}\text { Castro dei Volscei, Ferme de Grâce } \\
\text { Monte Peglia, Arce, Fontana Liri, } \\
\text { Colle Marino, La Pineta, Irsina, } \\
\text { Korolevo, Kärlich A, Becov I-T, } \\
\text { Červeny Kopec, Azykh }\end{array}$ & $\begin{array}{l}\text { Meseta sites, Cueva Victoria, Aculadero, } \\
\text { Pointe aux Oies, Bibbona, Sandalja, } \\
\text { Staré-Mésto, Gerasimovka }\end{array}$ \\
\hline & $\begin{array}{l}\text { JARAMILLO EVENT } \\
\text { (normal) }\end{array}$ & 0,97 & $\begin{array}{l}\text { Stránská Skála“* } \\
\text { Vallonet, Soleihac }\end{array}$ & Ca'Belvedere, Saint Thibéry \\
\hline
\end{tabular}

" Early Acheulian (ex-kAbbevillian»).

** According to Azzaroli et al., 1988: 89. 
units, indicating a final Jaramillo dating (Thouveny and Bonifay, 1982: fig. 2). The fauna resembles that of Vallonet but is slightly younger (upper biozone 20).

3) Isernia La Pineta. Evidence appeared conflicting, at first. The microtine and large mammal fauna is exclusively Galerian (Sala, 1984), without Villafranchian holdovers, fitting within Cordy's (1982) zone V and Guérin's zone 22. The presence of D. hemitoechus and Arvicola would be compatible with a 380-480 ky dating (Cordy, 1982: tables 1, 2). Calibrations, however, show reversed polarity (McPherron and Schmidt, 1983), and repeated K/Ar dating, using biotite and then sanidine sampling materials, gives consistently an age over $0.73 \mathrm{my}$, in agreement with geomagnetism (Sevink et al., 1981; Delitala et al., 1983). The possibility that the tuff deposits containing the samples could have been redeposited (Segre, 1982: 587) seems ruled out by laboratory verifications. This dating, if accepted, implies that the lower time boundaries of certain early mid-Pleistocene mammals found in classic localities, e.g. Stránská Skála, Süssenborn, Voigstedt, must be pushed back (Azzaroli et al., 1987: 80). An earlier than expected presence of Arvicola in the Levant ('Ubeidiya site, Israel) suggests a precocious and extra-European origin (Tchernov, 1988b: 855), and is more compatible with a long chronology.

4) Other localities in Central and Southern Italy. These provide further valuable chronological indications for the early Lower Palaeolithic in Europe, thanks to well-established and calibrated, correlated sequences, from fluvio-lacustrine series and tephrochronological datum lines (Biddittu, 1984; Biddittu and Segre, 1982; Biddittu et al., 1979; Segre, 1978, 1984; Segre et al., 1984). Crossdated Latium occurrences show that Colle Marino, Fontana Liri and Arce predate the Latium volcanic eruptions (K/Ar dated at 706 ky), while Castro dei Volsci, Valchetta Cartoni postdate it slightly (700 ky). Further South, the stratigraphic and geomagnetic position (Baïssas, 1980) of the archaeological layers A and B of Venosa-Loreto would be later than the $\mathrm{K} / \mathrm{Ar}$ dated (811 to $830 \mathrm{ky}$ ) Vulture eruption. Combining this with the early Galerian megafauna could place layers A and B around 600 ky (Angelelli et al, 1978; Biddittu et al, 1979: 67). The in situ Irsina artifact find predates stratigraphically the Vulture eruption.

Summary. Relative chronologies and calibrations concur in showing that the oldest anthropic remains of Europe, with a cluster of dates from across Europe up to the Transcausus, document a hominid peopling of Europe during later lower Pleistocene times, instead of the mid-Pleistocene or early Brunhes datum line proposed previously. This nevertheless confirms that no human presence can be traced to Villafranchian times sensu stricto, that is before the Jaramillo event - the 1.7 my date postulated for the Chilhac artifacts is no longer tenable. The fauna used for dating is not associated with them (Texier, 1985). The synchronous appearance in Europe of both the first hominids and the Galerian fauna is potentially significant. It may merely be a case of chronological coincidence or prove to be a significant linkage.

The colonization of Europe apparently took place during moderate climatic conditions, equivalent with marine isotopic stage 23 and the Bavelian North Sea basin phase, and with Cordy's biozone I and Guérin's biozone 20. It was followed by the first European cold episode (isotopic stage 22) of late Matuyama, correlated with loess cycle $\mathrm{K}$ in Central Europe and datable to $782 \mathrm{ky}$ (Bonifay, 1980: figs. 1, 2, 3; Kukla, 1987: 42).

\section{Diagnosis}

The object is to establish the identity of the early Lower Palaeolithic of Europe: whether these occurrences belong to handaxe (Acheulian) or non-handaxe repertoires. A diagnosis may indicate a geographic origin and ancient hominid dispersal routes into Europe. These depended on palaeogeographic factors but archaeological diagnosis may point to specific alternatives.

Since the Acheulian is already present in Subsaharan Africa by $1.5 \mathrm{my}$, one assumes that this repertoire probably accompanied ancient humans when they colonized Western Eurasia, 200 or 300 ky and Europe, $900 \mathrm{ky}$ later. Diagnosis of Lower Palaeolithic occurrences beyond Subsaharan 
Africa therefore treat an Acheulian verdict as the null hypothesis, or that mode 2 (handaxe/cleaver) assemblage types constitute the oldest Palaeolithic horizon throughout Eurasia. The burden of proof rests on the alternative verdict: establishing the existence of a non-handaxe entity will require unequivocal empirical support and a coherent explanation.

The issue goes beyond a formal or contrived exercise, generated by an arbitrary dichotomy reminiscent of type-Fossil naiveties. A populational and polythetic approach to lithic assemblage analysis should not detract from recognizing technological «mutations» (Harrison, 1954) e.g. mode 1 to 2 and growing specialization in Palaeolithic repertoires.

Several causes may account for non-handaxe Lower Palaeolithic industry types in Eurasia: 1) the persistence of a formerly widespread "Epi-Oldowan" or "Pebble-culture" horizon, as mentioned earlier. This would require identifying isolating (mostly circumstantial) factors, once the Acheulian had emerged and dispersedy 2) an atypical Acheulian sample (e.g. Central Europe -Bordes, 1950b) or technological (e.g. the Clactonian -Ohel, 1979) facies; 3 ) modifications of the Acheulian, coalescing into autonomous traditions, such as the East Asian Complex, by a) adaptation to tropical forests or, with the "Clactonian," to European woodlands (Collins, 1969), and b) by "reduction-segregation" (Kroeber, 1948) within Europe (Narr, 1953).

Published descriptions - along with personal examination of much of the West European portion of the documents - of the early Lower Palaeolithic in Europe show a complete lack of handaxes and cleavers, the Porte du Bois locality excepted. This remains insufficient for a formal diagnosis -though, many specialists reach a similiar conclusion e.g. Bordes and Thibault, 1977; Santonja, 1983; Peretto and Piperno, 1985; Lumley et al., 1988; Segre et al., 1982 - until submitted to stringent criteria and alternative interpretations.

Verification criteria are the following:

1) Chronological overlap with the early Acheulian. Evidence supporting this comes from the Porte du Bois "Abbevillian" and other claims. The Abbeville site contained numerous handaxes, reportedly associated with a Galerian (or Guérin's zone 22 and Cordy's zone III) fauna from the whitish marls between the Upper and High terrace (Agache et al., 1963), datable to a temperate early mid-Pleistocene phase, probably Mindel (Bordes, 1968: 52). The artifacts, however, were retrieved long ago, without systematic excavations, leaving their provenience uncertain and unverifiable (Howell, 1966; Tuffreau, 1987). The handaxes' "archaic" appearance is due to discarded roughouts and without developmental significance. Other instances, e.g. in England (Kent's Cavern -Roe, 1981; Campbell and Sampson, 1971) which could date to a temperate, pre-Anglian episode (isotopic stage 13?) present similar dating and provenience difficulties. Alleged "Acheulian" artifacts (Adamenko and Gladilin, 1989: fig. 6, $\mathrm{n}^{\circ}$ 4) from the culture horizons VIII, VII of Korolevo (Ukraine), dated late Matuyama and $850 \mathrm{ky}$, are unconvincing.

Even accepting the Porte du Bois or Kent's Cavern dating (perhaps 600-700 ky) and a coexistence with the later portion of the non-handaxe horizon, would still leave the remainder without handaxe evidence.

Dating the initial Acheulian in Europe remains unsettled. The earliest date is from Fontana Ranuccio, at $458 \mathrm{ky}$ (Segre and Ascenzi, 1984), much later than the Colle Marino non-Acheulian (700 ky), also from the Anagni basin. The rich Pinedo site, in the Spanish Meseta, is associated with a fully Galerian fauna but without radiometric or geomagnetic dates. In Central Europe, Series II of the Staré Město locality, undated but perhaps of «inter-Mindel» age, contains crude-looking bifacial artifacts, at least one of which could be an atypical quartz handaxe (fig. 14, Chlachula, 1990, 1991) (3) The underlying Series I, without such implements, is late Matuyama.

At Korolevo, horizons VI, VB, dated after $500 \mathrm{ky}$ and 260, respectively, contain unquestionable handaxes (Gladilin and Sitlivyi, 1990: figs. 14, 16). Layers VI, V, at Azykh cave (Azerbaidjan) also contain handaxes (Liubin, 1989: fig. 4). The underlying late Matuyama layers X to VII, however, is

(3) We thank Dr. Jiri Chlachula, Calgary University, for valuable verbal and illustrated information concerning Starè Mesto. 
non-Acheulian. All the evidence surveyed, consequently, indicates that the eariiest Acheulian in Europe succeeds the early non-handaxe horizon, instead of being synchronous with it.

2) Sampling arguments. These could include:

a) taphonomic factors, such as negative consequences of repeated erosion cycles on archaeological preservation. This undoubtedly impoverished the record but the late Matuyama to early Brunhes evidence has yielded enough in situ and rich assemblages to suggest that at least a few handaxe finds should have turned up by now;

b) statistical. Handaxe/cleaver frequencies range from nil to high values within Acheulian assemblages but these implements can be found in numerically small assemblages. In fact, our data fail to show any covariations between assemblage sizes and handaxe/cleaver frequency variations. Single finds of these implements are also common in Africa or Eurasia. Several early non-Acheulian assemblages contain hundreds and thousands of artifacts but handaxes/cleavers still remain absent (El Aculadero, La Pineta, Ca' Belvedere, Venosa-Loreto). The steady accumulation of these occurrences throughout Europe suggests increasingly that handaxe manufacture was not taking place then;

c) activity facies could introduce sampling biases because butchering or lithic quarrying did not require using handaxes or cleavers. Information about techno-economic organization during the early Palaeolithic horizon in Europe is poor. Where these activities are identified, large non-handaxe shaped implements are present (El Aculadero, Pointe aux Oies, Bibbona, Casella di Maida) but in similar Acheulian occurrence types (Aridos, Cagny-la-Garenne, Markkleeburg), handaxes (or bifacial trimmers) are found.

3) Raw material properties. Texture, shape and sizes of lithic resources could restrict handaxe manufacture. Coarse-grained materials such as lydite, quartz, are untractable and if used, would produce atypical implements. The raw material diversity encountered throughout Europe for the early Palaeolithic horizon, however, transcends such contingencies or circumstances. Furthermore, Fontana Ranuccio contains a typical limestone handaxe and many Acheulian, particularly cave (La Chaise, Pech de l'Aze, Combe-Grenal) sites, recognizable handaxes made of poor quality materials.

The shape e.g. cobbles or pebbles, did not impede handaxe/cleaver manufacture (Spanish Meseta, Upper Garonne, Central Italy). By contrast, the earlier La Pineta contained suitably-shaped tabular flint in addition to limestone, yet without any traces of handaxe-making. Small nodules or pebbles could impede effectively the manufacture of such implements, as was probably the case at Vértesszöllos or Bilzingsleben, but experiments at El Aculadero establish that handaxes could be made from medium and moderately small pebbles, if intended. Many early non-Acheulian sites contain heavy-duty tools which could have been shaped into handaxes.

In summary, the early Palaeolithic horizon contains too many instances where raw material conditions allowed a mode 2 technology.

\section{Implications}

The most economical verdict would seem that the existence of a non-handaxe horizon in Europe is more apparent than real and that such occurrences represent a facies or atypical variant of the Acheulian technocomplex. Nevertheless, we observe that a) no demonstrable chronological overlap exists between non-handaxe occurrences and the earliest Acheulian and b) sampling biases or influences of discrete circumstance must be ruled out because this early horizon shows too much internal and contextual variability, as well as geographical dispersion across Europe.

The weight of evidence indicates rather that it constitutes a separate, polythetic technocomplex. The interrelation of morphological traits (mode 1 technology), non-random chronological (late Matuyama to early Brunhes) and geographical (Europe) clumping authorizes rejecting the null hypothesis that this entity fits within the range of variation of the Acheulian technocomplex, because mode 2 technology is consistently absent. It suggests that ancient hominids occupying

T. P., 1992, $\mathrm{n}^{2} 49$ 
Europe between 0.90 and 0.55 my never acquired or had already abandoned handaxe/cleaver manufacture.

Naming this entity "Pre-Acheulian» (Biddittu, 1984: 35), "Archaic Palaeolithic" (Santonja, 1982; Segre et al, 1982: 199), "Pebble-Culture" (Kretzoi and Vértes, 1965) or early "Clactonian" (Collins, 1978: 55), raises interpretative issues: a) "Pre-Acheulian", while culture-stratigraphically correct inside Europe, remains relative and provisional, since the Acheulian outside Europe is as old or older; b) "Archaic" or "Pebble-Culture», beyond a descriptive usage, implies linear affinities with the chronologically distant Oldowan; c) "Clactonian" may bestow an exclusively European identity but Clactonian sensu stricto is confined to scarce fully mid-Pleistocene occurrences in England, while existing analytical methods cannot discriminate techno-typological differences between it and the Oldowan. For these reasons, we shall refer henceforth to this technocomplex as the European Early Palaeolithic Horizon, provisionally.

We face the following issues: 1) finding its origin or derivation and 2) how this may indicate hominid penetration routes into Europe.

The idiosyncrasies of the European Early Palaeolithic Horizon could be derived internally or outside Europe. The first alternative means that the Acheulian repertoire was modified to meet environmental circumstances within Europe, analogous to those invoked for East Asia. The horizon's time duration is substantial and contains several cyclical palaeoclimatic cycles but this is not correlated with concommitant changes in toolmaking repertoires. It should be added that the European Pleistocene environment retained the kind of vegetation mosaic that was compatible with ancient hominid food-getting strategies involving carnivorous exploitation and lithic technology, developed in Africa, maintained in Eurasia, except for Southeast Asia.

It seems reasonable to conclude that the characteristics of this technocomplex were derived outside Europe. This happened either by retaining, under unspecified isolating conditions, an Oldowan-like or mode 1 technology, or by reduction-segregation of the Acheulian repertoire.

\section{ANCIENT HOMINID DISPERSAL ROUTES INTO EUROPE}

This section tries to identify colonization routes into Europe by examining: 1) three independent and possibly concurring lines of evidence, namely locating non-Acheulian antecedent repertoires outside Europe; mammalian dispersal events, i.e. African carnivore expansion into Eurasia and Galerian dispersal; palaeogeographic conditions delimiting population movements; 2) three alternative hominid expansion routes: the Levant corridor, a conspicuous starting point for movements into Southeastern Europe; the oft-mentioned crossing routes across Gibraltar or the Siculo-Tunisian strait to Iberia or Italy; another, more roundabout, hitherto little considered, from a Central Asia staging area, through a filter route along the Palaearctic region's southern margin.

\section{Southwest Asia: the Levantine corridor}

This constitutes the most economical hypothesis. The region is a natural crossroad between Africa and Asia, with converging vegetation belts (Horowitz, 1979: ch. 2; Zohary, 1962), and a logical bottleneck for faunal exchanges with Northeast Africa, with dry land intercontinental connection (Bar-Yosef, 1987; Tchernov, 1987). It offers a gradual transition from tropical to subtropical zones. Acheulian occurrences from South to North (Goren, 1981; Hours, 1975; Muhesen, 1981; Yalcinkaya, 1981), are concentrated along fossil drainage systems (Gilead, 1975: figs. 1, 2) in grassland habitats with gregarious game, reminiscent of African landscapes familiar to ancient hominids and carnivores. How the Levant was settled remains unclear and beyond the scope of this paper but evidence now favours a lower Pleistocene Bab al Mandib landbridge crossing from the Horn into the Western Arabian peninsula.

T. P., 1992, n 49 
1. Lower Palaeolithic evidence. Most of it is recent Acheulian. The issue is to ascertain whether non-Acheulian occurrences exist in the region, sufficiently early to be geographical antecedents for their European counterparts. The record, though slender, is adequate for a verdict. It includes findspots, with or without handaxes in Lebanon (Borj Qinnarit), Northern Syria (Sitt Markho, Jebel Idriss, Sheikh Muhamad, Sharia, Khattab, Muharde II: Besançon et al., 1977; Hours, 1981; Hours and Sanlaville, 1972: Muhesen, 1981). 'Ubeidiya, Central Jordan Valley, Israel, remains the most informative site (Bar-Yosef, 1975, 1988).

Dating. All occurrences date to lower Pleistocene phases and roughly penecontemporaneous. Dating, 'Ubeidiya excepted, relies on lithostratigraphy and scant fauna. 'Ubeidiya's age, though better substantiated, has been debated. Preliminary faunal analysis and $\mathrm{K} / \mathrm{Ar}$ dates indicated around 700 ky (Bar-Yosef and Tchernov, 1972; Haas, 1973; Siedner and Horowitz, 1973), a datum line for the peopling of Eurasia. New findings push this further back in time: a) a faunal list revision led Fejfar and Repenning (1982) to a 2.5-1.9 my dating, implying also an extra-African origin for Homo erectus and the Acheulian, a view challenged (Jaeger, 1983; Opdyke et al., 1983); b) definitive fauna analyses (Eisenmann et al, 1983; Tchernov, 1987, 1988) indicate rather a 1.4 to 1.0 my age; c) geomagnetic and new K/Ar datings of the Yarmuk and Naharayim basalts, overlying the 'Ubeidiya formation, show 850 and $840 \mathrm{ky}$ and reversed polarity, thus a post-Olduvai and pre-Jaramillo age, I.25 my being a reasonable approximation.

Diagnosis. Verdicts concerning occurrences from Syria and Lebanon have oscillated, with various labels such as "Pebble-Culture», "Para-Acheulian", "Early Acheulian" (Hours, 1975; Hours and Copeland, 1973; Muhesen, 1988), in view of the presence or absence of handaxes. Assemblages from 'Ubeidiya, with or without handaxes - the latter initially called local variant of the Oldowan (Stekelis, 1966)-, are interstratified, 'Ubeidiya is now classified as early Acheulian (Meignen, 1983). All this early Lower Palaeolithic displays the inter-assemblage variability observed in the East African Acheulian (Davis, 1980; Gowlett, 1988). Splitting these occurrences into separate coexisting industries would be arbitrary. Sedimentology at 'Ubeidiya shows a covariation between biface and non-biface layers with changes in the sites microenvironmental setting, more in agreement with facies variations (Bar-Yosef, 1988: 772).

The early Lower Palaeolithic from the Levant, 'Ubeidiya particularly, documents the oldest anthropic traces in Eurasia. Its Acheulian identity, however, rules it out as an antecedent for the European Early Palaeolithic Horizon.

2. Biogeography. A simultaneous occurrence of anthropic remains and African carnivores would reinforce Turner's hypothesis about a widespread dispersal event out of Africa through the Levant. The spotted hyena ( $C$. crocuta) is present at 'Ubeidiya but African lion e.g. at Yabrud, Syria (Solecki and Solecki, 1966) or leopard remains e.g. Karain cave, Turkey (Yalcinkaya, 1988: 215) are late midPleistocene, leaving the spotted hyena the only species associated with the first hominids in the region. This generalization remains provisional, given the scarcity of fossil mammal sites in Southwest Asia (Jaeger, 1983) and that carnivores are rare fossils (Savage, 1978: 249). Early lion remains are common in Europe: e.g. lower B horizon, Graues Mosbach (Schütt, 1969), Mauer, Stránská Skála (Thenius, 1971), Tiraspol', Moldavia (Gromov, 1970), La Pineta, as is the leopard (e.g. Mosbach, Stránská Skála, Azykh) and the spotted hyena e.g. Domegliara, Süssenborn, Gomgaszög, Mosbach (Schütt, 1971), Mauer, Cromer Forest Bed, Stránská Skála (Kurtén, 1971). Datings suggest an earlier presence of the hyena: mid-Pleistocene 1(ii) (Kurtén 1968: table 15) y biozone 20 (Guérin, 1983); a Jaramillo event for Domegliara (Azzaroli, 1983: fig. 1) -but both the lion and leopard are placed in Cordy's biozone III later than the Soleihac and Vallonet Palaeolithic sites- the latter may contain single teeth specimens of the lion and leopard, however (Lumley et al., 1988). European evidence then shows a more or less synchronous appearance of hominids and African carnivores but Southwest Asia, a logical expansion route from Africa, presents a time-lag for the felids.

3. Palaeogeography. Hominids moving beyond the Levant had to negotiate physico-ecological barriers (Howell, 1960), with a string of mountain ranges (Kurd, Amanus, Anti -and Central Taurus), leading Northeast to the Armenian Knot, a high elevation barrier with a harsh, cold climate 
(Fisher, 1963: 330-332). Several of these mountains were not impenetrable e.g. the Cilician Gate, but piedmont areas occupation remained apparently marginal for small, dispersed and technologically limited early hominids, until they developed a transhumant settlement system, adapted to altitudinal biozonation (Smith, 1986: 10), later in the Pleistocene.

Reaching Europe by crossing the Anatolian plateau meant settling in an arid, low primary productivity region - except for inland depressions- then moving along a more favourable northern Anatolian tectonic trough and valley system (Fisher, 1963: 316-317; Redman, 1978: fig. 2.5). Lower Palaeolithic evidence on the plateau coincides with later Acheulian findspots (Minzoni-Deroche and Sanlaville, 1988; Yalcinkaya, 1988). Circumventing the central plateau by moving Northeast meant entering the inhospitable Eastern Anatolian highlands. Following the narrow Mediterranean coastal strip up to the Antalya Plain would be impeded further North or West, by another isolating barrier, the Western Taurus (Fisher, 1963: 322) whose role is confirmed by the area's Quaternary fauna endemism.

In summary, the Levant corridor seems a natural colonization route toward Europe (e.g. Foley, 1987: fig. 10.1), but closer scrutiny of the evidence does not support this prediction: significant physico-ecological barrier, delaying human implantation; the early Acheulian, an unlikely antecedent for the Early Palaeolithic Horizon in Europe.

\section{The Ibero-Moroccan and Siculo-Tunisian straits}

We review possible hominid dispersal routes across the West Mediterranean straits, with emphasis on Gibraltar.

Alleged Pleistocene connections between Africa and Europe through Mediterranean islands landbridges, Sicily and Tunisia particularly, were refuted by studies of insular dwarf elephant species (Vaufrey, 1929), amplified by other findings on dwarfism and gigantism (Thaler, 1973).

The rationale for direct connections between the Maghreb and Iberia or Italy has rested on arguments of Lower Palaeolithic assemblage similarities. This distributional and geographic contiguity criterion brings up the question of Pleistocene dry land or water crossing, especially for Gibraltar, revived by recent bathymetric findings. Biogeography, by contrast, seems of marginal or negative significance (Agustí et al., 1983: 20).

Physical barriers. The narrowest water barrier $(15 \mathrm{~km})$ between North Africa and Europe is a stretch from Tarifa to Punta del Carnero, Spain, and from Alcazarseguer to Punta Leon, Morocco. Alimen (1975) estimates, from bathymetric studies and sea-floor mapping by echo soundings, submarine surface photos and deep-sea cores (Stanley, 1972), that dry land crossing became feasible when seal levels dropped to $-290 \mathrm{~m}$, creating a South-North narrow $(23 \mathrm{~km})$ isthmus from East of Tangier and West of Tarifa. Current action has prevented Pleistocene sea-floor sediment accumulation (Ketting and Stanley, 1972: 494-496) and there is no evidence for significant neotectonic uplift.

Glacio-eustatic lowering favouring dry land or water crossings of narrow channels, however, existed only during Riss glacial much later than the hominid peopling of Europe.

Water crossing at any time (Bordes and Thibault, 1977; Chard, 1963), on the other hand, implied watercraft navigation, difficult to document directly, and did not eliminate the problem of strong current velocity, increasing with narrow channels. Findings also indicate intense pelagic transport during glacio-eustatic phases (Huang and Stanley, 1972: 552). Circumstantial support for movements across Gibraltar is therefore inconclusive.

Biogeography. North Africa formed an Ethiopian biogeographic island during the Pleistocene, dominated by Chado-Zambezian accacia-savannas, incorporating later a few mammal immigrants along a South Mediterranean corridor (Arambourg, 1960: 108-109; Biberson, 1968: 124-125; Cooke, 1963: 68, 71; Geraads, 1980: 91; Jaeger, 1975: 414), implying a lack of landbridge connections with Iberia.

T. P., 1992, $\mathrm{n}^{2} 49$ 
North African equivalents of Villafranchian mammals are found at Fourarat, Oued Akrech, Aïn Boucherit, lake Ichkeul, Aïn Brimba and lack entirely fossil or archaeological anthropic remains. African carnivores appear during or after the mid-Pleistocene transition, and associated with anthropic remains: the spotted hyena at Ain Hanech, slightly younger than 'Ubeidiya (Tchernov, 1988), at Tighenif (Ternifine) and Carrière Thomas, around $700 \mathrm{ky}$ (Geraads, 1980); the lion and leopard were reported also at Tighenif (Jaeger, 1975: 402) but not definitely (Geraads et al, 1986: 383).

The Levant and Maghreb thus document a simultaneous appearance of hominids and $C$. crocuta beyond Subsaharan Africa, before or after $1.0 \mathrm{my}$, and perhaps the lion and leopard in the Maghreb in North Africa by $700 \mathrm{ky}$. This evidence is too slender to show felid or hominid dispersal routes into Europe but a Gibraltar crossing is not entirely ruled out (Geraads, 1980), by a "sweepstake" dispersal movement (Agustí et al., 1983: 20). North African gerbils and amphibians are reported from Cueva del Higuerón and Las Yedras, Southern Spain (López Martínez, 1972; López Martínez and Ruiz Bustos, 1977), perhaps by land crossing or introduced by prey birds (Santonja, 1983: 9). Another North African species (P. miocaenicus) is known in Spain since the Miocene but could have reached both sides of the Mediterranean from its Asiatic homeland separately. These exceptions emphasize the lasting effectiveness of the Gibraltar barrier.

Lower Palaeolithic evidence. A case for hominid dispersal through Gibraltar stands or falls, ultimately, on archaeological proofs.

1) The Acheulian. Occurrences concentrated of both sides of Gibraltar were regarded as a positive indication (Chard, 1963) for a distributional argument until nullified by discoveries from around the entire Mediterranean basin e.g. Palaiokástron, Greece (Higgs, 1963). Specific technotypological trait discriminants e.g. handaxe and cleaver manufactured on sidestruck flake preforms in Africa, or handaxe typological attributes, also reported in Iberia (Alimen, 1975; Riet Lowe, 1932, 1945: 59; Freeman, 1975; Rolland, 1986) have also been invoked in favour of connections. Several of these actually recur in Iberia and Southwest France - flint handaxes or cleavers made on sidestruck flakes at San Isidro, or Les Pendus (Bergeracois).

These traits may provide clues about diffusionary movements out of North Africa, becoming more diluted as they spread deeper into Western Europe, and perhaps even about the European early Acheulian's (e.g. Pinedo) origin, but need closer investigation. The model may prove more plausible than the debatable (see Villa 1983) notion of a "Southern Acheulian" province (Bordes, 1971). In any case, it would have taken place too late to be a colonization event, an issue left without real discussion in Alimen (1975).

2) The "Pebble-Culturew. This Lower Palaeolithic entity represents the only conceivable North Africa antecedent for the European Early Palaeolithic. Recognizing and defining it (Alimen, 1957; Balout, 1955: 159-172) as a separate Northwest African repertoire was belated, on account of a Eurocentric research outlook and the disrepute of the "Eoliths" debate in Europe (Biberson, 1961b: 23-27). Reported from Algeria (Mansourah plateau, Ain Hanech), Morocco and the Northwestern Sahara, the most thoroughly described documentation comes from the Casablanca area, Atlantic Morocco where it is fitted into a long lower Pleistocene succession, based on marine glacio-eustatic and continental cycles series (Biberson, 1956, 1961a, b, 1968, 1970; Choubert, 1962).

Detailed but schematic subdivisions within protracted Early and Evolved stages, served to identify gradual techno-typological developments, leading to an in situ transition into the Acheulian. The sequence, thought to parallel the East African Oldowan to Acheulian succession, has also been used for long-distance crossdating within Africa (Balout, 1981: 569) and Europe (Bordes and Thibault, 1977). An apparent concentration of artifact-bearing localities similar to El Aculadero, along the southwestern coast of Spain, in addition to other finds from the peninsula (Santonja, 1983), would not be incompatible with the notion of direct connections with North Africa, although we note that reliable "Pre-Acheulian" occurrences from Iberia, providing a counterpart repertoire for the "Pebble-culture" across Gibraltar remained unreported (Freeman, 1975: 733; Zbyszewski, 1976) until recently.

The Moroccan Pebble-Culture sequence nevertheless contains flaws: a) lack of biostratigraphic, 
geomagnetic and radiometric dating, b) absence of fossil hominids, whose identity, given the postulated relative chronology, could be Australopithecus or Homo habilis. H. erectus is known from mid-Pleistocene sites in the region and at Tighenif, c) accounting for the local Acheulian's late appearance (Alimen, 1977), not earlier than late Matuyama or isotopic stage 22 (Texier et al, 1986: tables 1, 2), despite a proposed local linear transition from the Pebble-Culture, and implying a cultural lag (McBurney, 1975: 413).

New researches by Bordeaux University's Institut du Quaternaire and Moroccan institutions have revamped radically this Atlantic Morocco Pleistocene sequence and its palaeoclimatic interpretation (Raynal et al., 1986a, b; Texier et al, 1985). Furthermore, critical evaluations of the provenience, retrieval conditions and identity of the area's Pebble-Culture raise serious doubts about its reality in North Africa (Butzer, 1982: 43). This negative verdict has been confirmed since by Bordeaux University researchers (4).

Removing the controversial Maghreb Pebble-Culture has fundamental implications: 1) it resolves chronological and developmental discrepancies between that region's Palaeolithic and the East African master sequence, where the Acheulian emerges early, linked with $\mathrm{H}$. erectus; 2 ) it supersedes the concept of an early and widespread diffusion of an Oldowan or "Pebble-Culture" Palaeolithic substratum across Africa and Eurasia and its postulated "persistence" in certain regions; 3) it eliminates the last criterion left for considering a hominid peopling of Europe directly out of Northwest Africa; 4) the Acheulian constitutes the earliest Palaeolithic horizon in North Africa and is penecontemporaneous with the European Early Palaeolithic Horizon. These conclusions, therefore, add to the series of inconclusive claims made over the years about Ibero-Moroccan prehistoric contacts, prior to the Neolithic (see Ripoll López and Cacho Quesada, 1990; Villaverde Bonilla and Fumanal García, 1990, concerning the Solutrian in Spain).

The Siculo-Tunisian landbridge. Recent reports of Acheulian (Graziosi, 1968) and Pebble-Culture in Sicily (Bianchini, 1969) have revived the question of Pleistocene connections with Tunisia. Pebble tool finds need confirmation and connections will remain conjectural until systematic geochronological and palaeogeographic researches will be carried out (Segre et al., 1982: 183-184, 192). They must also take due account of recent findings concerning the existence of a Pebble-Culture in the Maghreb.

The Italian peninsula's configuration with its narrow, compartmentalized structure, surrounded by the Mediterranean and bound by the Alps, was markedly modified during Pleistocene ice ages. Its major geographical links then were to the East, with the emergence of the Adriatic-Ionian shelf into a shallow marshy plain (Mussi, 1990: 139 and fig. 7.1). The density of Early Palaeolithic occurrences, their presence across the Adriatic-Ionian seas (Visgliano, Sandalja, Nea Skalá) and Southeast (Yarm Burgaz) may hold clues about a more significant palaeogeographic orientation of hominid movements.

\section{The Central Asia migration filter}

Lower Palaeolithic, biogeographic and palaeographic evidence fail to establish conclusively a hominid dispersal route through the Levant or the Maghreb into Europe. The search for nonhandaxe repertoires, as antecedents for the European Early Palaeolithic Horizon, must therefore move beyond the Southern and Eastern Mediterranean basin, whether such a technocomplex constitutes a linear continuation of the Oldowan or one derived from the Acheulian. Africa is ruled out since the Oldowan is confined to Eastern and Southern Africa, from the Horn to the Transvaal. The only alternative left, inside Eurasia, is the remote Chopper-Chopping Tool Complex in the Far East. It was concluded earlier that this represented a permanently modified version of the Acheulian rather than an isolated persistence of mode 1 (Oldowan) technology.

(4) Field evidence shows that all the occurrences are either recent or belong to the Acheulian, or non-artifactual. We owe this information to Jean-Paul Raynal, Insitut du Quaternaire, Bordeaux University (Brive, August 1990). 
Direct long-distance connections between non-handaxe industries of Europe and East Asia have been alluded to, largely with reference to the Clactonian (Oakley, 1961: 48, 1969: 144, 1972: 50; Sieveking, 1962: 125-126) or those from Eastern Europe (Bordes, 1968: 69; Collins, 1969; Kretzoi and Vértes, 1965). Substantiating this implies finding archaeological, biogeographic and palaeogeographic evidence connecting these subcontinental extremities of Eurasia. Routes connecting them run necessarily through the Palaearctic faunal region which comprised several provinces e.g. SinoSiberian and Central Asiatic, during the Pleistocene (Bonifay, 1979: fig. 2; Kahlke, 1986: fig. 1; Vangengeim and Sher, 1970).

1. The Eurasian biogeographic corridor. It illustrates connections and continuities of mammalian species between Western Europe and China, through Mongolia, Siberia and Eastern Europe, fostered by common bioclimatic and ecological factors (Simpson and Beck, 1965: 734), including the Pleistocene (Alekseev, 1970; Kurtén, 1975; Sher, 1975). Corridors, like barriers, are never absolute and favour or impede certain species. Homo erectus' technological development was probably insufficient for overcoming bioclimatic obstacles of the Eurasian corridor: the cold Siberian taiga with its low animal and food resources (Chard, 1974: 5), during interglacials; the cold, continental steppe biome, to which hominids adapted only by the Lower to Middle Palaeolithic transition, during glacials. Movements into the western portion of the corridor were also more restricted by large glacial lake barriers in Western Siberia and the Khvalyn depression.

Lower Palaeolithic finds from Siberia, Mongolia, Northern Kazakhstan or the Russian plain are scant and controversial. Researchers acquainted with artifactual evidence from the Ulalinka site, dating to over $1.5 \mathrm{my}$, in the Altai, do not accept them as humanly made (Ivanova, 1982: 384. Kozlowski, 1987: 301; Laming-Emperaire, 1978; Powers, 1973). This climatic barrier, therefore, prevented a successful occupation prior to the upper Pleistocene (McBurney, 1976).

2. The Central Asia filter. This region comprises Soviet Central Asia, Afghanistan and Western China (Xinjiang/Uighur region, Qinghai and Inner Mongolia). It is a landmass completely cut off from oceanic influences, bound to the North by the Siberian taiga, to the South by a string of high mountains and plateaus, while retaining narrow internal communication lines or funnels (Hambly, 1969: 4-5). It is regarded as inhospitable, unattractive for human settlement because of its arid, harsh climate, scarce in food supplies and difficulties of access (Ranov, 1972).

It attracted first the attention of palaeogeographers and palaeontologists as a conjectural hominoid primate evolution centre and even of human origins, since de Quatrefages, Osborn, Black and some Russian scholars, although this has been abandoned since, in the absence of any evidence (see Okladnikov, 1972; Teilhard de Chardin, 1953).

Early Palaeolithic Evidence Fieldwork. Logistic difficulties and unfavourable preservation or accessibility conditions, due to intensive erosion and deposition, meant that proofs of Palaeolithic occupation appeared slowly, firstly reaching no further back than the Middle Palaeolithic e.g. Teshik-Tash cave and other sites (Movius, 1953; Davis, 1978; Davis and Dupree, 1977; Dupree et al., 1970; Gábori, 1987; Ranov, 1976; Ranov and Davis, 1979).

Eventually, several Lower Palaeolithic discoveries have pushed back steadily the date of initial human settling of the region (Ranov, 1984). These documents benefit from a reconstructed regional Pleistocene sequence, based on river terraces, loess deposits, tectonics and mammalian biostratigraphy, calibrated by geomagnetic and TL dating (Dodonov and Ranov, 1977, 1984; Ranov and Davis, 1979).

These Lower Palaeolithic occurrences include: 1) surface finds from the Dasht-i-Nawur palaeolacustrine shores (Afghanistan -Davis, 1978); 2) from the On-Orcha river (Kirghizia); 3) the KukhiPiyéz site, Vakhsh river, south Tadjikistan. All are dated to early mid-Pleistocene from geological evidence; 4) better dated stratified sites, of late mid-Pleistocene age from the 5th palaeosol, dated 130-150 ky by TL, at Lakhuti 1, and from the 6th palaeosol, dated 194-210 ky, at Karatau 1. These dates are regarded as minimum (Ranov and Davis, 1979); 5) artifacts, perhaps $500 \mathrm{ky}$ from the

\section{T. $P ., 1992, \mathrm{n}^{2} 49$}


Khonako section (Gábori, 1987; Dodonov and Ranov, 1977; Ranov, 1984); (5) the oldest evidence comes from the stratified site of Kul'dara, from the 11th and 12th palaeosols, dating to late Matuyama, between 750-850 ky, again in Tadjikistan (Davis, 1987; Dodonov and Ranov, 1984; Ranov, 1984: 9; Ranov et al., 1987). All these assemblages were made of small or large pebbles and cobbles. They are often dominated by flake implements (scrapers, points, serrated tools), with many choppers and chopping-tools. Added to these is the Sel'ungur cave site (Kirghizia), with similar artifacts and a few teeth or bone fragments attributed to Homo erectus (Islamov, 1990; Islamov et al., 1988).

Chronology. The detailed loess and palaeosols stratigraphies from which these occurrences came, complemented by geomagnetic and TL dating, provide a roughly reliable time framework. The record shows Kul'dara as the only late Matuyama anthropic site, so far, in Central Asia but as is the case for 'Ubeidiya, concerning the Levant and Eurasia as a whole it constitutes a significant datum line for Central Asia. Its archaeological contents have also implications because of a complete absence of handaxes (unlike 'Ubeidiya), making it a plausible landmark between Europe and the Far East.

Another observation of interest is that although fauna at the site was scarce and unidentified, the site is close to and belongs to the same time-stratigraphic unit as the Lakhuti 2 faunal locality (Ranov et al., 1987: 69-70). Lakhuti 2 contains a characteristic Galerian fauna of late Matuyama age (Azzaroli, 1983). Another Galerian faunal site in the region is Koshkurgan, of early Brunhes ages (Azzaroli et al, 1988: fig. 6). Sel'ungur's basal layers apparently contain similar elements (E. stenonis) though no artifacts. It is worth stressing this simultaneous occurrence of the region's earliest Lower Palaeolithic and first Galerian fauna, as well as recalling that this region was also the Galerian's initial evolution and dispersal centre.

Diagnosis and origins. None of the above mentioned assemblages contain any traces of an Acheulian or mode 2 technology, the attribution of the Sel'ungur industry to a "Southern Acheulian" is inappropriate: the term is used exclusively for Southwestern Europe; the Sel'ungur artifact illustrations are not recognizably Acheulian. This absence is attributed partly to raw material constraints (we know, however, that Acheulian handaxes are made of poor materials unless minimal sizes or certain untractable materials would become an impediment), partly to a local tradition (Ranov, 1982). Central Asia does show evidence for a continuing use of pebble materials, up to the Neolithic.

Scattered handaxe finds have actually been reported, as predicted by Ranov and Davis (1979: 255) but these are clustered in the westernmost margin of Central Asia (Turkmenia, western Kazakhstan). While undated, most appear to belong to the Middle Palaeolithic and a few to a late Acheulian probably synchronous with the Caucasus cave Acheulian (Vyshnyatsky, 1989a). Unless new discoveries reverse this generalization, the Lower Palaeolithic of Central Asia adds to evidence suggesting that certain portions of Eurasia were occupied by populations without a mode 2 repertoire (Vyshnyatsky, 1989b).

The genesis of Lower Central Asia's Lower Palaeolithic is unclear although Kul'dara has stimulated new discussions. Mentioned affinities with Southern and Eastern Asia, implying direct connections with South Asia, are problematic (Ranov and Davis, 1979: 255). These become even more questionable because the Sohanians's reality is doubtful. Furthermore, the presence since the Miocene, of major mountain barriers has impeded northward movements (Heintz and Brunet, 1982).

Kul'dara's antiquity led some researchers to shift a search for phyletic affinities directly with East Africa and the Oldowan, supported by a string of early occurrences in Western Eurasia: 'Ubeidiya, Azykh, Korolevo, Sandalja, Bečov, Vallonet (Gladilin and Ranov, 1986), thus reaffirming or implying the notion of an Oldowayen repertoire precocious dispersal. A closer look at the evidence cited reveals that these Lower Palaeolithic occurrences constitute a lumping of distinct Lower Palaeolithic repertoires: a) 'Ubeidiya is early Acheulian and also the earliest dated site in

(5) Artifacts found by I. Mochanov in the Lena River area, are claimed to be over 1.0 my (Davis, 1987: 300) but little detailed information has reach this writer yet. 
Eurasia; b) the others, from Kul'dara to Vallonet, are non-Acheulian - but not «belated Oldowan"and a little later than 'Ubeidiya. It is recalled that the Acheulian supersedes the Oldowan by $1.4 \mathrm{my}$ in Subsaharan Africa.

A legitimate alternative, though requiring a more detailed hypothesis and needing archaeological support, would be to look again for direct connections inside Asia but within the Palaearctic region, in the direction of Northern China. Recently dated sites there indicate a lower Pleistocene hominid occupation (Xihoudou, the Nihewan basin sites), around 1.1-1.0 my. This date, combined with their non-Acheulian artifactual pattern, make them a credible antecedent for a similar industry in Central Asia and perhaps ultimately of the European Early Palaeolithic Horizon.

These affinities between Central and East Asia remain hypothetical, arrived at by deduction (by eliminating South Asia or East Africa) and circumstantial, and without known Lower Palaeolithic in the intermediary, Western China, region. Two observations are made regarding this: 1) research experience in Central Asia has shown that Lower Palaeolithic discoveries are difficult to make, requiring intensive, repeated fieldwork, and will remain few in number; 2) Quaternary research in Western China indicates that hominid settlement conditions were more favourable during the lower Pleistocene than this presently inhospitable region would indicate.

Western China is characterized by a harsh, desert (Ala Shan, Qaidam, Takla Makan) climate. 'Only narrow river valleys are suitable for settlement and communication, although the Qaidam depression experiences better moisture retention with streams from the Kunlun mountains (Petrov, 1962). The long-term orogenic uplift trends creating these arid continental conditions have operated since the Miocene, with gradual isolation from monsoonal influences (Wang Pinxian, 1984; Zhoo Songgiao and Xing Jianing, 1984; XuRen, 1984).

Palaeoclimatic reconstructions, however, indicate that although this basic pattern was already in place by the lower Pleistocene, the trend increased until Neothermal times, underlying climatic fluctuations. The Qaidam basin and Yellow River areas had a milder, wetter climate then, becoming drier and colder from the mid-Pleistocene onwards (Wang Kelu et al, 1988; Zhang Lansheng, 1988; Zhen Benxiang, 1988; Jiang De-Xin, 1988). These findings provide palaeogeographic support for a possible westward hominid dispersal around 1.0-1.1 my, along narrow river valleys (Sulo He, Tarim) and palaeolakes margins, ultimately reaching Central Asia (Kirghizia, Uzbekistan, Tadjikistan, Afghanistan) by a filter route between the Tien Shan and the Pamirs.

3. Dispersal route into Europe. In this section, we identify; 1) routes available to ancient hominids dispersing from Central Asia toward Europe, along the southern Palaearctic region, 2) Lower Palaeolithic occurrences linking both regions and 3) localities with end-Villafranchian/Galerian fauna. The purpose is to examine the extent of overlap between these lines of evidence. Positive findings would give initial support for a hypothesis a) linking the non-Acheulian of Europe with that of Central Asia into a single repertoire, b) that processes underlying such a connection could relate to a dispersal event involving both hominids and the Galerian mammal species.

Dispersal route. The most natural one, west of Central Asia, would involve avoiding the northern deserts (Kizil Kum, Kara Kum), moving south of the Kopet Dagh and Elburz, along the more attractive alluvial fans habitats at the edge of these mountains and flanking the northern inland deserts of the Iranian plateau (Spooner, 1972). There is evidence for Pleistocene fossil or enlarged lakes, especially in the Northeast (Smith, 1986: 11). Contacts to the south across deserts probably never took place until late prehistoric times and the advent of animal transport and long-distance trade. The southern deserts would be especially forbidding. Beyond this, movements would lead westward into the favourable habitats of the Transcaucasus and then, along the north Anatolian tectonic trough towards the Bosphorous and into Southeastern Europe. Alternatively (or additionally), glacioeustatic lowering of the Black Sea would liberate substantial areas of presently submerged land in the Sea of Azov and west of Crimea.

Lower Palaeolithic landmarks. These remain sparse and scattered widely, outside Europe, particularly in Iran where Palaeolithic research has been marginal: the Kashafrud basin finds, in Khorassan, Northeastern Iran, Azykh cave (Azerbaidjan), Gerassimovka (Azov coast, Russia), and 
Yarım Burgaz (Turkish Rumelia). The Kashafrud finds (Abravan, Baghbaghu), several of which are in stratigraphy or with known provenience (Ariai and Thibault, 1975-77), come from fossil lacustrine contexts. Artifactual inventories are similar to those from Europe and Central Asia. Dating is imprecise, based on geology but the finds' position in the terrace stratigraphic sequence indicates considerable antiquity. Their location, adjacent to Central Asia, is also interesting, lending credence to suggestions that the earliest occupants of the Iranian plateau conceivably came from that region (Smith, 1986: 14). Another potentially important though poorly dated occurrence comes from Iranian Azerbaidjan (in Smith, 1986) would also fit the dispersal trajectory proposed here.

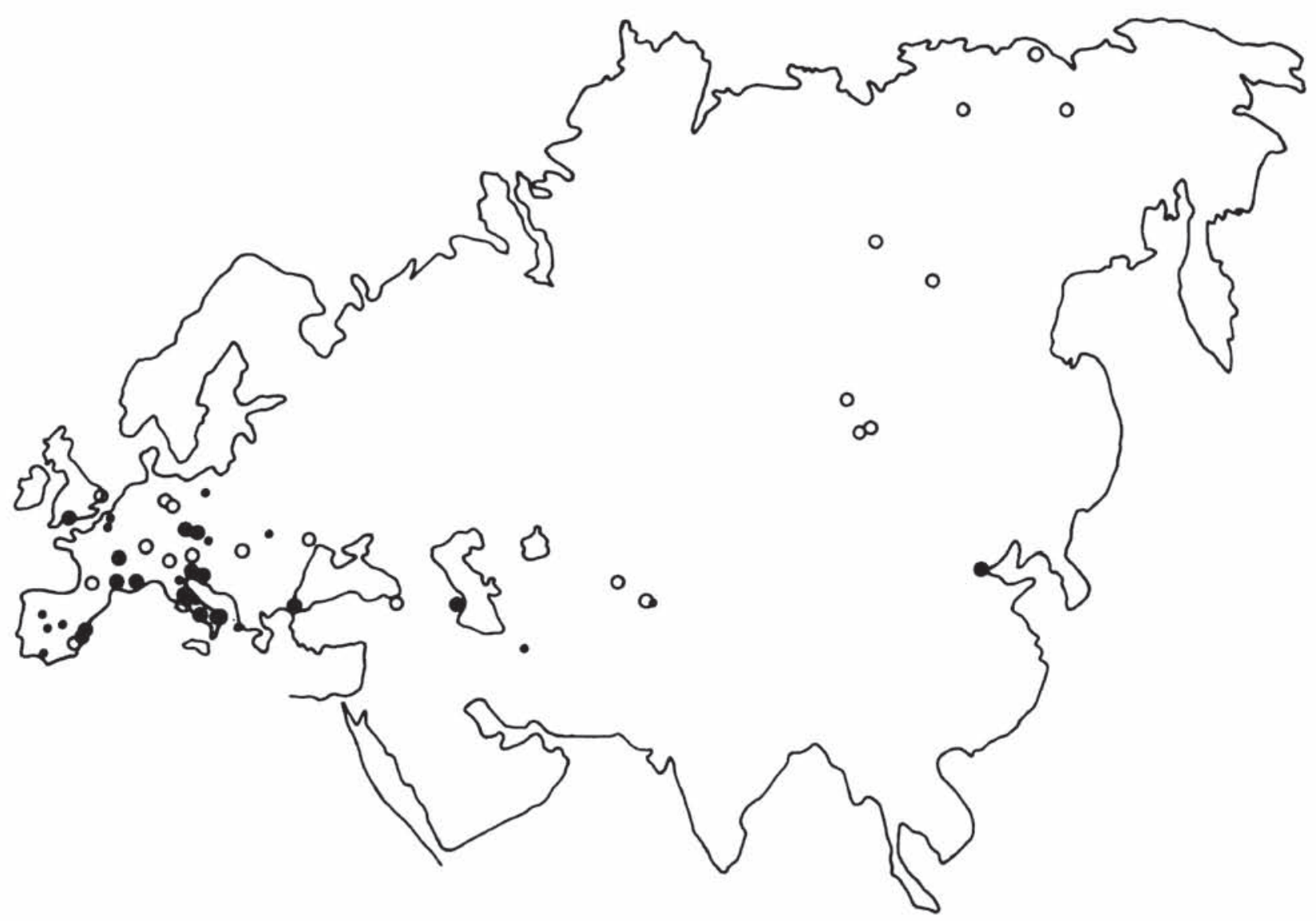

FIG. 1.-Geographic distributions of Galerian fauna and non-Acheulian occurrences (based on Azzaroli, 1983; Azzaroli et al., 1988; Bonifay, 1979, 1980).

Galerian mammalian fauna occurrences.

non-Acheulian Lower Palaeolithic occurrences.

occurrences where Galerian fauna and non-Acheulian are associated.

Clustering of occurrences within Europe indicates that research has been more intensive there. Note that Galerian faunal sites in Central and Northeastern Siberia are entirely without Palaeolithic associations. Blanks for Western Siberia show that Galerian fauna occurrences there are scarce, with poor assemblages. Lower Palaeolithic sites there are unknown. 


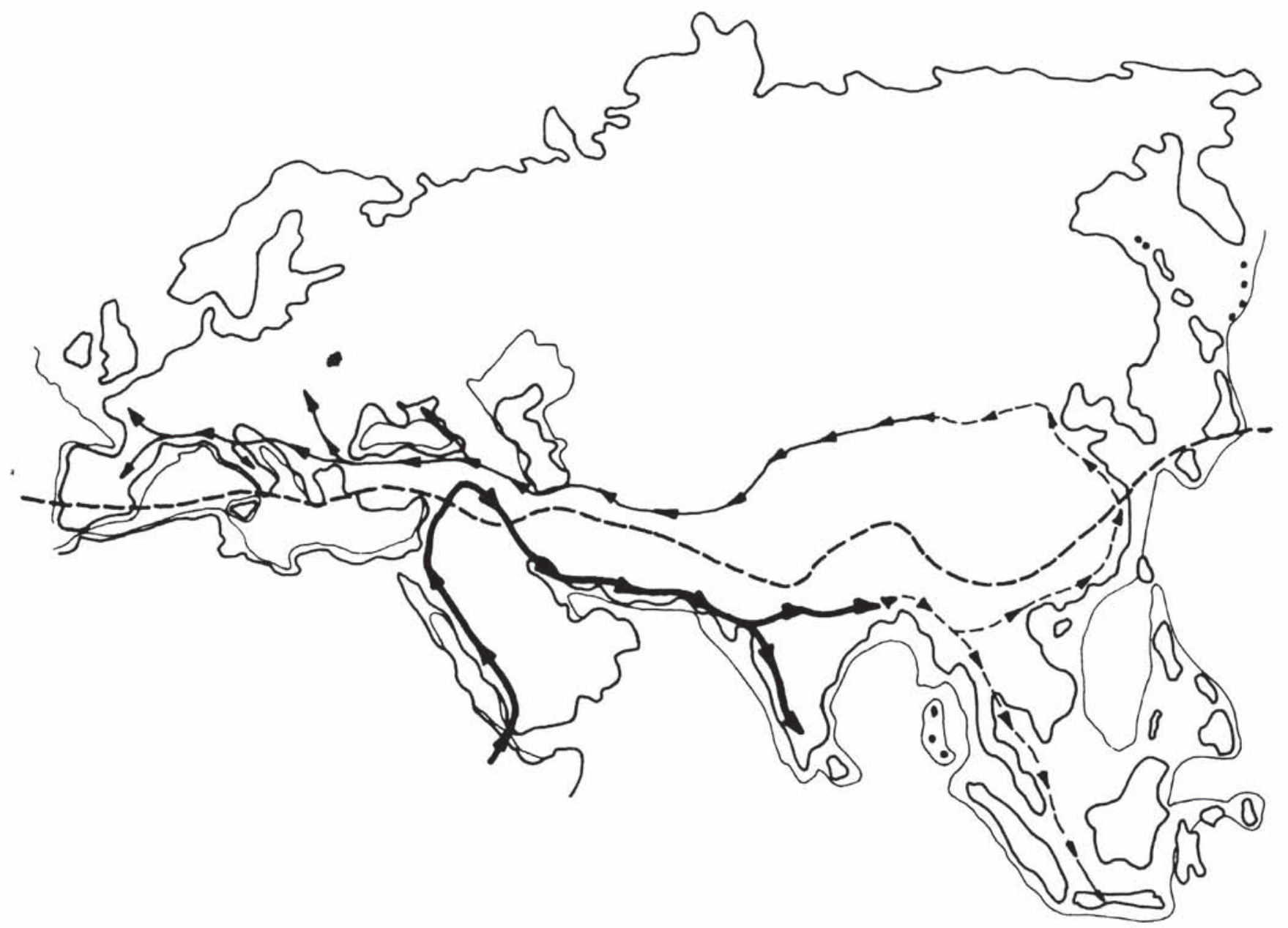

FIG. 2.-Hypothetical early hominid dispersal routes out of Africa, through southern Eurasia, and westward into Europe (based on Howell, 1960; Oakely, 1964; Whithing et al., 1982)

initial dispersal from East Africa up to Southeast Asia;

$-\rightarrow \quad$ continuing dispersal through the Southeast Asian tropical forest filter route, then along the temperate, broad-leaf forest habitat of coastal China, and through the arid continental arid zone filter of Western China.

$\longrightarrow \quad \longrightarrow \quad$ the southern Palaearctic filter route, from Central Asia into Europe,

$10^{\circ} \mathrm{C}$ mean temperature isotherm durint coldest month in the Northern hemisphere.

Pleistocene glacio-eustatic coastal contour of Eurasia.

The large-scale loop shown on the map traces hominid population dispersal route circumventing the major East-West trending mountain barrier of Eurasia.

T. P., 1992, $\mathrm{n}^{2} 49$

(c) Consejo Superior de Investigaciones Científicas

http://tp.revistas.csic.es

Licencia Creative Commons 3.0 España (by-nc) 
Faunal localities. The list, also small between Central Asia and Europe, contains a few landmarks: Azykh, Akhalkalaki, Georgia (Vereshchagin, 1967: 155), Yarmm Burgaz.

Linkage with dispersal events. The end-Villafranchian/Galerian fauna spread from its Central Asia centre in several directions, mainly northeast into Siberia and to the West into Europe (Azzaroli et al, 1988: fig. 2). Europe's greater site concentration reflects more intensive coverage. Figure 1 plots Galerian fauna sites and non-handaxe Lower Palaeolithic sites, from Central Asia to Europe. A noticeable geographical overlap emerges, including many sites where both lines of evidence are associated. This overlap is partial, since mammals dispersed in multiple directions across their continental realm whereas hominids followed an apparently linear pattern. The latter illustrates, of course, only one species' dispersal, which in the case of Homo erectus probably confined itself to more familiar home ranges. The Siberian faunal sites are entirely without artifacts.

This broadly cohesive time-space patterning in Western Eurasia of early Palaeolithic occurrences with the Galerian fauna suggests a broader event, analogous to that earlier one proposed by Turner for hominids and carnivores out of Africa. Azzaroli identifies the probable causes (tectonics, climatic deterioration) for the large-scale late lower Pleistocene end-Villafranchian/Galerian turnover across temperate Eurasia. The hominid populations who were beginning to people Central Asia undoubtedly felt the repercussions of these profound perturbances, such as shifting home ranges pressures to adjust to game animal dispersions.

The hypothesis contains weak and strong points. The former include: 1) a sparse often poorly dated archaeological evidence, outside Europe; 2) a major archaeological documentary gap between Central Asia and North China; 3) the geographical overlap of Lower Palaeolithic and Galerian sites may be without significance if hominid movements proceeded out of Europe, in a direction opposite to the Galerian fauna dispersal. This objection, however, cannot be tested because chronological data are too broad to detect age-area patterns but if considered seriously, it would leave unanswered the question of the European Early Palaeolithic Horizon's origin.

The strong points are: 1) it provides the only plausible explanation left for the early European non-handaxe technocomplex; 2) the overlapping patterns require an interpretation; 3 ) the model is the only one without conflicting evidence; 4) its «long journey" scenario for the peopling of Europe, shown on Figure 2, takes into consideration the physiographic configuration of much of Eurasia and its East to West trending, which conditioned movements and isolation. This orogenic barrier also accounts for the persistence in isolation, from North China to Europe, of an initially Acheulian repertoire, modified permanently once hominids moved into the tropical Indo-Malaysian forest; 5) the hypothesis is open to refutation by empirical evidence, such as if early Acheulian sites were discovered in Europe, Central Asia or China.

As it stands, this hypothesis is based on goodness of fit of evidence and merely represents an exploratory model in need of a larger data base. It may not be the most economical explanation but prehistory and biogeography both contain ample instances of protracted, reticulate events.

\section{CONCLUSION}

The paper synthesizes current knowledge about the Palaeolithic colonization of Europe. Like any surveys of this kind, it can become rapidly obsolete, as new evidence is added, some of which may require radical revisions of viewpoints presented here. The main focus was on the question of the nature and origin of the earliest Palaeolithic horizon in Europe and along with it, of population movement routes followed by ancient hominids.

Three main alternatives were considered, with respect to colonization routes: through the Levant, across Gibraltar, out of Central Asia and ultimately, northern China. None have been established conclusively yet but the latter, linking hominid and Galerian faunal dispersal, is more cohesive and without data incompatibility. It is a preliminary testable hypothesis, but there is a pressing need to improve the quantity and quality of its data-base, particularly in regions such as Southeastern 
Spain, the loess regions of Central Europe, Central Asia and especially, Western China. New empirical findings, however, may invalidate entirely this third alternative. What has been covered represents only one aspect of the theme of Palaeolithic colonization of Europe. Other key topics would include reconstructing ancient hominid socio-ecology, adaptive processes under earlier Pleistocene bioclimatic conditions in temperate Eurasia, the role of predation, of fire making, settlement systems but all would require a much richer documentation.

\section{BIBLIOGRAFIA}

Adamenko, O. M. and Gladilin, V. N. (1989): «Korolevo. Un des plus anciens habitats acheuléens et moustériens de transcarpathie soviétiquex. L'Anthropologie, 93 (4): 689-712.

adamenko, O. M.; Adamenko, R. S.; Gladilin, V. H.; Grodetskaia, G. D.; Levkovskaia, G. M.; Pashkevich, G. A.; Pospelova, G. A.; Kulakovskaia, L. V. and Shelkoplias, V. N. (1989): «Paleoliticheskoe mestonakhozhdenie. Korolevo v zakarpatien. Biuletin Komissii po izuchenio chetvertichnogo perioda, 58: 5-25.

Agache, R.; Bourdier, F. and Petri, R. (1963): «Le Quaternaire de la basse Somme: tentative de synthèsen. Bulletin de la Société géologique de France, 5 (7): $422-442$.

Agusti, J.; Gibert, J. and Moýi.Solí, S. (1983): «El "Hombre de Orce”. Su significado en la evolución de los primeros pobladores de Europan. Revista de Arqueología, 29: 17-21.

Agustí, J. and Moýa.SolÁ, S. (1987): «Sobre la identidad del fragmento craneal atribuido a Homo sp. de Venta Micena (Orce, Granada)n. Estudios Geológicos, 43: 535-538.

AIGNER, J. S. (1978): «Important archaeological remains from North Chinaw. In F. Ikawa-Smith (ed.): Early Palaeolithic in South and East Asia, Mouton. The Hage: 163-231.

Alexseev, M. N. (1970): «An occurrence of Tiraspolian fauna at the Vilyuy River (Eastern Siberia)n. Palaeogeography, Palaeoclimatology, Palaeoecology, 8 (2/3): 209-214.

Alekseev, M. N.; Deviatkin, E. V.; Arkhipov, S. A.; Lauthin, S. A.; Grinenko, O. V. and Kamaletdinov, V. A. (1984): «Problemy chetvertichnoi geologii Sibirii, International Congress (27th, 1984, Moscow)-Quaternary Geology and Geomorphology, Section C.03, Reports vol. III: 3-12. Izdatel'stvo «Naukaw. Moscow.

Alferez Delgado, F. (1977): «Estudio del sistema de terrazas del río Tajo al W. de Toledo». Estudios geológicos, 33: 223-250.

Alimen, H. (1957): The Prehistory of Africa. Hutchinson. London.

- (1975): "Les "isthmes" hispano-marocains et Siculo-tunisiens aux temps Acheuléens». L'Anthropologie, 79 (3): 399-436.

- (1977): «Considérations sur la chronologie de l'Acheuléen africain». Bulletin de la Société Préhistorique Française, 74: 42-51.

ANDREWS, P. and CRONIN, J. E. (1982): «The relationship of Sivapithecus and Ramapithecus and the evolution of the orang-utan». Nature, 297: 541-546.

angelelui, F.; Caloi, A.; Malatesta, A. and Palombo M. R. (1978): «Fauna quaternaria di Venosa: cenni preliminari». Atti della XX riunione scientifica dell'Istituto Italiano di preistoria e protostoria (Basilicata, 1976): 133-140; Stamperia Editoriale Parenti, Florence.

antoniazzi, A.; Cattani, L.; Cremaschi, M.; Fontana, L.; Peretto, C.; Posenato, R.; Proli, F. and Ungaro, S. (1988): "Le gisement du Paléolithique inférieur de Ca'Belvedere di Monte Poggiolo (Forli, Italie) (Résultats préliminaires)». L'Anthropologie, 92 (2): 629-642.

ARAMBouRG, C. (1960): «Les faunes mammalogiques du Pléistocène circumméditerranéen». Quaternaria, 6: 97-109.

ARIAI, A. and THIBAULT, C. (1975-77): «Nouvelles precisions à propos de l'outillage paléolithique ancien sur galets du Khorassen (Iran)». Paléorient, 3: 101-108.

Ayres, W. S. and SONG NAI RheE (1984): "The Acheulian in Asia?: a review of "Research on Korean Palaeolithic Culture"\#. Proceedings of the Prehistoric Society, 50: 35-48.

Azzaroli, A. (1983): "Quaternary mammals and the "end-Villafranchian" dispersal event -a turning point in the history of Eurasian. Palaeogeography, Palaeoclimatology, Palaeoecology, 44: 117-139.

- (1985): «Provinciality and turnover evens in Late Neogene and Early Quaternary vertebrate faunas of the Indian subcontinent». In V. G. Gupta (ed.): Contributions to Himalayan Geology, 3, Hindustan Publishing Corporation. Delhi: 27-37.

Azzaroli, A.; DE Givli, C.; Ficcarelli, G. and Torre, D. (1988): «Late Pliocene to early mid-Pleistocene mammals in Eurasia: faunal succession and dispersal eventsw. Palaeogeography, Palaeoclimatology, Palaeoecology, 66: 77100.

AzZaroli, A. and NAPOleone, G. (1982): «Magnetostratigraphic investigation of the Upper Sivaliks near Pinjor, Indian. Rivista Italiana di Paleontologia, 87 (4): 739-762.

T. P., 1992, $\mathrm{n}^{2} 49$ 
BaIssas, P. (1980): «Données paléomagnetique et sédimentologique sur les dépots de la coupe de Loreto». Musée d'Anthropologie Préhistorique de Monaco, 42: 13-56.

Balout, L. (1955): Préhistoire de l'Afrique du Nord. Arts et metiers graphiques. Paris.

Bartholomew, G. A. and Birdsell, J. B. (1959): «Ecology and the protohominids". In Morton H. Fried (ed.): Readings in Anthropology. Thomas Y. Crowell. New York: 46-62.

BAR-Yosef, O. (1975): «Archaeological occurrences in the middle Pleistocene of Israel». In K. W. Butzer and G. Isaac (eds.): After the Australopithecines. Mouton. The Hague: 571-604.

- (1987): „Pleistocene connexions between Africa and Southwest Asia: an archaeological perspectiven. The African Archaeological Review, 5: 29-38.

- (1988): «Le Paléolithique d'Israel». L'Anthropologie, 92 (3): 769-795.

BAR-Josef, O. and Tchernov, E. (1972): On the Palaeo-Ecological History of the Site of Ubeidiya. Israel Academy of Sciences and Humanities. Jerusalén.

Bianchini, G. (1969): «Manufatti della "Pebble culture" in Sicilian. Rivista di Szienze Preistoriche, 24 (1): $171-180$.

Bidprtru, I. (1972): «Pleistocene e industrie litiche pre-Acheuleane ad Arce e Fontana Siri (Frosinone)». Quaternaria, 16: 35-52.

BiBERSON, P. (1956): «Nouvelles précisions sur les gisements à "Pebble-Culture” des plages marines soulevées du Quaternaire ancien de Casablanca (Maroc)». Comptes Rendus de l'Académie des Sciences de Paris, 243B (Serie D): 1.227-1.229.

- (1961): Le cadre paléogeographique de la préhistoire du Maroc atlantique. Edita. Casablanca.

- (1962): Le Paléolithique inférieur du Maroc Atlantique. Publications du Service des Antiquités du Maroc, 17. Rabat.

- (1970): "The problem of correlations between South Europe and North Africa during the Pleistocenew. Paleogeography, Palaeocliatology, Palaeocology, 8: 113-127.

BidDrTtu, I. (1984): "Le piu antiche industrie del Paleolitico inferiore del Lazio». Atti della XXIV riunione scientifica dell'Istituto Italiano di preistoria e protostoria (Lazio, 1982): 31-37. Stamperia Editoriale Parenti. Florence.

Biddittu, I.; Cassoli, P. F.; Radicati di Brozolo, F.; Segre, A. G.; Segre; Naldini, E. and Villa, I. (1979): «Anagni, a K-Ar dated lower and middle Pleistocene site, Central Italy: preliminary report». Quaternaria, $21:$ 53-71.

BIDDITTU, I. and SEGRE, A. (1982): "Pleistocene medio-inferiore con industria arcaica su ciottolo nel bacino di Agnani (Lazio)». In A. Broglio, A. Palma di Cesnola and A. M. Radmili (eds.): Il Paleolitico inferiore in Italia. Atti della XXIII riunione scientifica (Firenze, 1980): 567-576. Istituto italiano di preistoria e protostoria. Florence.

BIGALKE, R. C. (1968): «Evolution of mammals on Southern continents. III. The contemporary mammals of African. The Quarterly Review of Biology, 43: 265-300.

BINFORD, L. R. (1981): Bones: Ancient Men and Modern Myths. Academic Press. New York.

Biouand, D. (1987): «Les formations villafranchiennes du bassin du Puy-en-Velay et du plateau de Perrier, Massif Central, France. Conséquences chronostratigraphiques des études paléomagnétiques». L'Anthropologie, 91 (1): 5-28.

BLumENSChine, R. J. (1987): «Characteristics of an early hominid scavenging niche». Current Anthropology, 28 (4): 383-407.

BONIFAY, E. (1980): «Haute-Loire-Blanzac». Gallia-Préhistoire, 23 (2): 341-344.

- (1981): «Les traces des premiers hominidés en France". La Recherche, 12 (128): 1.442-1.444.

- (1989): "Un site du très ancien Paléolithique de plus de 2 m.a., dans le Massif Central français: Saint-Eble-Le Coupet (Haute-Loire)m. Comptes Rendus de l'Académie des Sciences de Paris, 308 (Série II): 1.567-1.570.

Bonifay, E; Bonifay, M. F.; Panattoni, R. and Tiercelin, J. J. (1976): «Soleihac (Blanzac, Haute-Loire), nouveau site préhistorique du début du Pléistocène moyen". Bulletin de la Société Préhistorique Française, 73: 293-304.

Bonifay, E.; CONSIGNY, A. and Liabeuf, R. (1989): «Contributions du Massif Central français à la connaissance des premiers peuplements préhistoriques de l'Europe». Comptes Rendus de l'Académie des Sciences de Paris, $30 \dot{8}$ (Série II): 1.491-1.496.

Bonifay, E. and Tiercelin, J. J. (1977): «Existence d'une activité volcanique et tectonique au début du Pléistocène moyen dans le bassin du Puy (Haute-Loire)n. Comptes Rendus de l'Académie des Sciences de Paris, 284 (Serie D): $2.455-2.457$.

BoNIFAY, M. F. (1979): «Interrelations entre les grandes faunes Plio-Pléistocènes eurasiatiques et origine des faunes françaises». Quaternaria, 21: 9-16.

- (1980): «Relations entre les données isotopiques océaniques et l'histoire des grandes faunes européennes pliopléistocènesw. Quaternary Research, 14: 251-262.

- (1983): «Paléontologie des grands mammifères: les périodes récentes représentent-elles un domaine particulier de recherches?». In F. Poplin (ed.): La faune et l'homme préhistorique. Mémoires de la Société Préhistorique Française, 16: 19-23.

BONNEFILle, R. (1979): «Méthode palynologique et reconstituions paleóclimatiques au Cénozoique dans le Rift Est Africain». Bulletin de la Société géologique de France, 21 (3): 331-342.

Bordaz, J. (1970): Tools of the Old and New Stone Age. Natural History Press. New York. 
BORDES, F. (1950): «L'évolution buissonnante des industries en Europe occidentales. Considérations théoriques sur le Paléolithique ancien et moyenn. L'Anthropologic', 544: 393-420.

- (1953): «Préhistoire et méthodes géographiquesw. L'Ánthropologie, 57: 570-575.

- (1961): Typologie du Paléolithique Ancien et Moven. Delmas. Bordeaux.

- (1968): The Old Stone Age. McGraw-Hill. New York.

- (1971): «Observations sur l'Acheuléen des grottes en Dordognew. Munibe, 23: 5-24.

Bordes, F. and THIBAULT, C. (1977): «Thoughts on the initial adaptation of hominids to European glacial climates». Quaternary Research, 8: 115-127.

BorISKovSKII, P. I. (1978): «Some problems of the Palaeolithic of South and Southeast Asian. In F. Iwaka-Smith (ed.): Early Palaeolithic in South and East Asia. Mouton. The Hague: 87-95.

Bosinski, G. (1982): «The transition Lower/Middle Palaeolithic in Northwestern Germanyn. In A. Ronen (ed.): The transition from Lower to Middle Palaeolithic and the Origin of Modern Man, BAR S151. Oxford: 165-176.

Botella LópeZ, M. (1975): «El Cazadero achelense de la Solana del Zamborino (Granada)». Actas del XIII Congreso Nacional de Arqueologia (Huclva, 1973). Zaragoza: 175-184.

Botella López, M.; Vera, J. and de Porta, J. (1975): "El Yacimiento Achelense de la "Solana del Zamborino", Forelas (Granada)m. Cuadernos de Prehistoria de la Universidad de Granada, 1-4: 1-45.

Bout, P. (1976): «Chronologie paléomagnetique du Massif Central volcanique de la France en relation avec les ages absolus $\mathrm{K} / \mathrm{Ar}$, les faunes de mammifères et les épisodes périglaciaires". In H. de Lumley (ed.): $L a$ Préhistoire Française, 1: 362-364. C.N.R.S. Paris.

BOUT, P. and DE GOER DE HERVE, A. (1976): "Le volcanisme préquaternaire, pléistocène et holocène dans le Massif Central français». In H. de Lumley (ed.): La Préhistoire Française, 1: 304-310. C.N.R.S. Paris.

Bout, P. and Veyret, Y. (1976): «Les dépots lacustres dans le Massif Central». In H. de Lumley (ed.): La Préhistoire Francaise. C.N.R.S. Paris: 188-191.

BRAIDWOOD, R. J. (1960): «Levels in prehistory: a model for the consideration of the evidence». In S. Tax (ed.): The Evolution of Man, Mind: Culture and Society. University Press. Chicago: 143-151.

Breuil, H. (1932): «Les industries à éclats du Paléolithique ancien». Préhistoire, 1 (2): 125-190.

Broglio, A.; Palma di Cesnola, A. and Radmilli, A. M. (eds.) (1982): Il Paleolitico inferiore in Italia. Alti della XXIII riunione scientifica (Firenze). Istituto Italiano di Preistoria e Protostoria. Florence.

BunN, H. T. (1981): «Archaeological evidence for meat-eating by Plio-Pleistocene hominids from Koobi Fora and Olduvai Gorgew. Nature, 291: 574-580.

BunN, H. T. and KROLL, E. M. (1986): «Systematic butchery by Plio-Pleistocene hominids at Olduvai Gorge, Tanzaniew. Current Anthropology, 27 (5): 431-452.

BuRdUKIEWICZ, J. M. (1990): «Wyniki badań stanowiska dolnopaleoliticznego Trzebnica 2n. Ślaskie Sprawozdania Archeologiczne, 31: 7-24.

BURDUKIEWICZ, J. M. and WINNICKI, J. (1988): «Trzebnica-najstarsze slady obecnosci czlowieka na ziemiach polskich». Towarzystwo Mitosnikow Ziemi Trzebnickiej Trzebnica: 1-12.

Butzer, K. W. (1982): "The paleo-ecology of the African continent». In J. D. Clark (ed.): The Cambridge History of Africa, vol. 1: ch. 1. University Press. Cambridge.

CAMPBELL, B. (1972): «Man for all Seasons». In B. Campbell (ed.): Sexual Selection and the Descent of Man 1871. 1971. Aldine. Chicago: 40-58.

CampBell, J. B. and Garth SampSon, C. (1971): «A New Analysis of Kent's Cavern, Devonshire, England». University of Oregon Anthropological Papers, 3.

Carbonell, E.; Guilbaud, M. and Mora, R. (1984): «Amplification du système analytique avec la classification des techno-complexes à galets taillés». Bulletin de la Société Préhistorique Française, 81 (7): 203-206.

Chaline, J. (1982): «Les rongeurs de la grotte du Vallonet (Alpes-Maritimes), l'environnement et l'áge du site». L'Anthropologie, 92: 497-499.

CHARD, СH. S. (1963): «Implications of early human migrations from Africa to Europen. Man, 63 (152): 124.

- (1974): «Northeast Asia in Prehistory». University of Wisconsin Press. Madison.

ChepalygA, A. L. (1984): «Inland sea basins». In A. A. Velichko (ed.): Late Quaternary Environments of the Soviet Union. University of Minnesota Press. Minneapolis: 229-247.

Chiapella, V. G. (1964): «Il Paleolitico inferiore di Venosa». Bulletino di Paletnologia Italiana, 73: 6-23.

CIOCHON, R. L. (1983): «Hominoid cladistics and the ancestry of modern apes and humans: a summary statement». In R. L. Ciochon and R. S. Corrucini (eds.): New Interpretations of Ape and Human Ancestry. Plenum. New York: 783-843.

Chlachula, J. (1990): "The early Palaeolithic settlement in the region of the middle course of the river Morava (Czechoslovakia)". Anthropologie (Brno), 28 (2-3): 241-248.

- (1991): "The early Palaeolithic settlement at the Staré Město locality, southeastern Moravia, Czechoslovakia». In Civilisations et industries du Paléolithique inférieur et moyen. Section III 2, U.I.S.P.P. (Bratislava, 1991): 17 pp.

ChouberT, G. (1962): «Reflexion sur les parallélismes probables des formations quaternaires Atlantiques du Maroc avec celles de la Méditerranéew. Quaternaria, 6: 137-176.

ChUnG, Y. W. (1984): «Acheulian handaxe culture of Chongok-ni Korean. In R. O. White (ed.): The Evolution of the East Asia Environment, II. Centre of Asian Studies, Hong Kong: 894-914.

T. P., 1992, $\mathrm{n}^{2} 49$ 
CLARK, J. D. (1975): “Africa in prehistory: peripheral or paramount?». Man, 10: 175-198.

- (1976): "The African origins of Man the toolmakem. In G. Isaac and E. R. McCown (eds.): Human Origins: Staples Press. Menlo Park: 1-53.

Clark, J. G. (1977): World Prehistory in New Perspective. Cambridge University Press.

Clermont, N. and Sмith, P. E. L. (1980): «La conquête des latitudes nordiques par les hominidés du Quaternaire». Géographie physique Quaternaire (Montréal), 34 (2): 221-228.

Collina-Girard, J. (1978): «Evolution des industries à galets aménagés de la vallée de la Têt (Pyrenees-Orientales)». Bulletin de la Société Préhistorique Française, 75 (6): 172-180.

Collins, D. (1969): "Culture traditions and environment of early man». Current Anthropology, 10: 267-316.

- (1976): The Human Revolution from Ape to Artist. Phaidon. Oxford.

- (1978): "The Palaeolithic of Italy in its European context". In H. McK. Blake, T. W. Potter and D. B. Whitehouse (eds.): Papers in Italian Archaeology, I, The Lancaster Seminar. BAR S41(i), Oxford: 51-70.

- (1986): Palaeolithic Europe. A Theoretical and Systematic Study. Voybarger Books: (Tiverton). Ch, 12 Early Palaeolithic Settlement and Culture: 173-204.

Coltorti, M.; Cremaschi, M.; Delitala, M. C.; Esu, D.; Fornaseri, M.; McPherron, A.; Nicoletti, M.; Otterlo, R. van; Peretto, C.; Sala, B.; SchmidT, V. and Sevink, J. (1982): "Reversed magnetic polarity at an early Lower Paleolithic site in Central Italyn. Nature, 300: 173-176.

Coltorti, M.; Cremaschi, M.; Guerreschi, A.; Peretto, C. and SAl.A, B. (1982): "L'accampamento preistorico di Isernia La Pinetan. In Atti della XVIII Riunione Scientifica: 577-587. Istituto Italiano di Preistoria e Protostoria. Florence.

COOKE, H. Basil (1963): «Pleistocene mammal faunas of Africa, with particular reference to Southern African. In F. C. Howell and F. Bourliere (eds.): African Ecology and Human Evolution. Methuen. London: 65-116.

- (1968): "Evolution of mammals on southern continents. III. The fossil mammal fauna of Africas. The Quarterly Review of Biology, 43: 234-264.

Cook, J.; Stringer, Ch. B.; Currant, A. P.; Schwarcz, H. P. and Wintle, A. G. (1982): «A review of the chronology of the European middle Pleistocene hominid recordn. Yearbook of Physical Anthropology, 25: 19-65.

Coppens, Yves; HowEl, P. Clark; Glyn, Isaac and LEAKEY, R. E. F. (eds.) (1976): Earliest Man and Environments in the Lake Rudolf Basin. Chicago University Press.

CORDY, J. M. (1982): «Biozonation du quaternaire post villafranchien continental d'Europe occidentale à partir des grands mammifèresw. Annales de la Société Géologique de Belgique, 105: 303-14.

Cremaschi, M. and Peretto, C. (1988): «Le Paléolithique inférieur de la plaine orientale du Pom. L'Anthropologie, 92 (2): 643-682.

Darlington, P. J. (1957): Zoogeography, the Geographical distribution of Animals. John Wiley. New York.

DAviEs, R. (1978): "The Palaeolithic of Aghanistan». In N. Hammond and B. Allchin (eds.): The Archaeology of Aghanistan. Academic Press. London.

- (1980): «Pleistocene archaeology in the southern Afghan-Tadzhik depression». Proceeding of the International Union of Geological Sciences/UNESCO Symposium of the Neogene/ Quaternary boundary, Dushambe, Tadzhikstan.

- (1987): «The implications of improved chronological determination for the Soviet Central Asian Palaeolithicn. In H. L. Dibble and A. Montet-White (eds.): Upper Pleistocene Prehistory of Western Eurasia. University of Pennsylvania Museum. Philadelphia: 297-301.

DAVIS, R. and DUPREE, L. (1977): «Prehistoric survey in central Afghanistan». Journal of Field Archaeology, 4: 139148.

Delttala, M. a C.; Fornaseri, M. and Nicoletti, M. (1983): «Datazioni argon-potassio sulla serie pleistocenica di Isernia La Pinetan. In C. Peretto, C. Terzani and M. Cremaschi (eds.): Isernia La Pineta. Calderini. Bologna: 6566.

DELSON, E. (1989): «Oldest Eurasian stone tools». Nature, 340: 96.

DenNelL, R. (1983): European Economic Prehistory. A new approach. Academic Press. London.

DENNELL, R. W.; RENDELL, H. and HAILWOOD, E. (1988): «Early tool-making in Asia: two-million-year-old artefacts in Pakistan*. Antiquity, 62: 98-106.

Dodonov, A. E. and RANOV, V. A. (1977): "Stupeni b Kamennyi vek». Znanie Sila, 601: 20-23.

- (1984): «Antropogen Srednei Azii: stratigrafia, korreliatsiia, paleolit». In International Geological Congress (Moscow, 1984), Section C.03: Quaternary Geology and Geomorphology, 3: 67-81.

Dreiman, R. (1983): «Les premiers habitants de l'Europe: qui sont-ils?». La Recherche, 14 (142): 388-390.

DUPREE, L. (ed.) (1972): «Prehistoric research in Afghanistan». Transactions of the American Philosophical Society, NS 62 (4): 3-84.

EATON, R. L. (1979): "Interference competition among carnivores: a model for the evolution of social behaviourn. Carnivore, 2: 9-16.

EisenmanN, V.; Ballesio, R.; Beden M.; Faure M.; Geraads, D.; Guerin, C. and Heintz, E. (1983): «Nouvelle interprétation biochronologique des grands mammifères d'Ubeidiya, Israẹl». Géobios, 16 (5): 629-633.

FARRAND, W. (1989): «Yarımburgaz Cave, Turkey (Summer 1989)». Old World archaeology Newsletter, 13 (3): 27.

FINK, J. and KuKLA, G. (1977): «Pleistocene climates in Central Europe: at least 17 interglacials after the Olduvai eventn. Quaternary Research, 7: 363-371. 
Fisher, W. B. (1963): The Middle East. A Physical, Social and Regional Geography. Methuen, London.

Foley, R. (1987): Another Unique Species. Longman Scientific and Technical. Harlow.

FreEmaN, L. G. (1975): «Acheulian Sites and Stratigraphy in Iberia and the Maghreb». In K. Butzer and G. Isaac (eds.): After the Australopithecines. Mouton. The Hague: 661-743.

- (1977): «Palaeolithic archaeology and palaeoanthropology in Chinaw. In W. W. Howells and P. J. Tsuchitani (eds.): Palaeoanthropology in the People's Republic of China. Washington. National Academy of Sciences. 79. 113.

GABEL, C. (1983): «The search for human origins: facts and queries». Journal of Field Archaeology, 10: 193-211.

Gabori, M. (1987): «Nouvelles découvertes dans le Paléolithique d'Asie Centrale soviétique». In Harold L. Dibble and Anta Montet-White (ed.): Upper Pleistocene Prehistory of Western Eurasia. University Museum. University of Pennsylvania. Philadelphia: 287-295.

GEIST, V. (1971): "The relation of social evolution and dispersal in ungulates during the Pleistocene, with emphasis on the Old World Deer and the genus Bisonw. Quaternary Research, 1: 283-315.

GeraAdS, D. (1980): «La faune des sites à «Homo erectus» des carrières Thomas (Casablanca, Maroc)». Quaternaria, 22: 65-94.

Geraads, D.; Hublin, J. J.; Jaeger, J. J.; Tong, H.; Sen, S. and Toubeau, P. (1986): «The Pleistocene hominid site of Ternifine, Algeria: new results on the environment, age, and human industriesw. Quaternary Research, 25: 380-386.

Giber, T.; Clols, J.; Campillo Valero, D. and García Olivares, E. (eds.) (1989): Los restos humanos de Orce y Cueva Victoria. Institut Paleontologic Dr. M. Crusafont. Barcelona.

GileAD, D. (1975): «Lower and Middle Palaeolithic settlement pattern in the Levantw. In F. Wendorf and A. E.

- Marks (eds.): Problems in Prehistory: North Africa and the Levante. Southern Methodistt University Press. Dallas: 273-282.

Gladilin, V. N. (1989): "The Korolevo Palaeolithic Site: research methods, stratigraphy». Anthropologie (Brno), 27 (2-3): 93-103.

- (1990): «Achel'Zakarpatia». In V. N. Gladilin and V. I. Satlivyi (eds.): Achel' tsentral'noi evropy. Naukova Domka. Kiev: 25-74.

Gladilin, V. and Ranov, V. (1986): „Ot Pamira do Karpat». Znanie Sila, 2: 29-31.

Gladilin, V. N. and Situivyı, V. I. (1990): Achel' tsentral'noi evropy. Naukova Dumka, Kiev.

GOREN, N. (1981): "The Lower Paleolithic in Israel and adjacent countries». In P. Sanlaville and J. Cauvin (eds.): Prehistoire du Levant. C.N.R.S. Paris: 194-205.

GowletT, John A. (1988): «A case of Developed Oldowan in the Acheulian?» World Archaeology, 20 (1): 13-26.

Graziosi, P. (1968): «Découverte d'outils du Paléolithique inférieur en Sicilen. L'Anthropologie, 72: $399-408$.

Gromov, V. I. (1970): "The Tiraspol faunal complex». Palaeogeography, Palaeoclimatology, Palaeoecology, 8 (2/3): 187-195.

GuÉRIN, C. (1983): «Première biozonation du Pléistocène européen, principal résultat biostratigraphique de l'étude des Rhinocerotidae (Mammalia, Perissodactyla) du Miocène terminal au Pléistocène supérieur d'Europe occidentalen. Géobios, 15 (4): 593-598.

Guerin, C.; Mourer-Chauvire, C.; Ballesio, R.; Faure, M. and Debard, E. (1983): «Biostratigraphie comparée des faunes des grands mammifères et d'oiseaux du Pléistocène moyen et supérieur en Europe occidentale et en URSS d'Europen. Bulletin de l'Association française pour l'Etude du Quaternaire, 20 (14-15): 133-146.

GuSEINOV, M. M. (1974): «Zhilishche drevneishego cheloveka v nashei stranien. Priroda, 3: 112.

GuTHRIE, D. (1984): "The Galerian Dispersal Event and the origin of the modern megafauna, its implications for Early Man in the Northern Hemisphere». The Quarterly Review of Archaeology, 5 (2): 15-16.

GutH, C. (1974): "Découverte dans le Villafranchien d'Auvergne de galets amenagés". Comptes Rendus de l'Académie des Sciences de Paris, 279 (Série D): 1.071-1.072.

HaAs, G. (1966): On the vertebrate fauna of the lower Pleistocene site Ubeidiya. Israel Academy of Sciences and Humanities. Jerusalem.

Hambly, G. (ed.) (1969): Central Asia. Wiendenfeld and Nicolson. London.

HAYDEN, B. (1977): «Sticks and stones: the Southeast Asian Upper Palaeolithic?». In J. Allen, J. Golson and R. Jones (eds.) Sunda and Sahul: Prehistoric Studies in Southeast Asia, Melanesia and Australia. Academic Press. New York.

HARRIS, J. W. K. (1986): «Découverte de matériel archéologique Oldowayen dans le Rift de l'Afar». L'Anthropologie, 90 (3): 339-357.

HaRrison, H. S. (1954): «Discovery, invention and diffusion». In Charles Singer, E. J. Holmgard and A. R. Hall (eds.): A History of Technology. I: Clarendon Press. Oxford: 58-84.

HEINTZ, E and BRUNET, M. (1982): "Une barrière géographique entre le sous-continent indien et l'Eurasie occidentale pour les faunes continentales du Miocène supérieurn. Comptes Rendus de l'Académie des Sciences de Paris. Série II, 294: 477-479.

Hemmer, H. (1982): "Considerations on socialty in fossil carnivores". South African Journal of Science, 78: 105107.

HigGs, E. S. (1964): «A Hand Axe from Greece». Antiquity, 38: 54-55.

HoRowitz, A. (1979): The Quaternary of Israel Academic Press. New York.

T. P., 1992, n² 49 
Hours, F. (1975): «The Lower Palaeolithic of Lebanon and Syria». In F. Wendorf and A. E. Marks (eds.): Problems in Prehistory: North Africa and the Levant. Southern Methodist University Press. Dallas: 249-271.

- (1981): «Le Paléolithique inférieur de la Syrie et du Liban. Le point de la question en 1980». In P. Sanlaville et J. Cauvin (eds.): Préhistoire du Levant. C.N.R.S. Paris: 165-168.

Hours, F.; Copeland L. and Aurenche, O. (1973): «Les industries paléolithiques du Proche-Orient. Essai de corrélation». L'Anthropology, 77: 229-280, 437-496.

HowelL, F. C. (1960): «European and Northwest African middle Pleistocene hominids». Current Anthropology, 1 (3): 195-232.

- (1966): "Observations on the earlier phases of the European Lower Palaeolithic". American Anthropologist, 68 (2), pt 2: 86-201.

Howell, F.; Haesaerts, C. P. and De Heinzelin, J. (1987): «Depositional environments, archeological occurrences and hominids from Members E. and F. of the Shungura Formation (Omo basin, Ethiopia)n. Journal of Human Evolution, 16: 665-700.

HuANG, Ter-Chien and Stanley, J. D. (1972): «Western Alboran Sea: sediment dispersal, ponding and reversal of currentsm. In D. J. Stanley (ed.): The Mediterranean Sea: A Natural Sedimentation Laboratory. Dowden, Hutchinson and Ross. Stroudsburg: 521-559.

Hours, F. and Sanlaville, P. (1972): «Découverte de silex taillés dans une plage située à + $95 \mathrm{~m}$ a Borj Qinnarit (Liban)w. Comptes Rendus de l'Academie des Sciences de Paris, 275 (Série D): 2.219-2.221.

HUTTERER, K. (1977): «Reinterpreting the Southeast Asian Palaeolithic». In J. Allen, J. Golson and R. Jones (eds.): Sunda and Sahul: Prehistoric Studies in Southeast Asia, Melanesia and Australia. Academic Press. New York: 31-71.

IKAWA-SMITH, F. (1978): «Introduction: the Early Palaeolithic tradition of East Asia». In F. Ikawa-Smith (ed.): Early Paleolithic in South and East Asia. Mouton. The Hague: 2-10.

ISAAC, G. L. (1974): "Stratigraphy and patterns of cultural change in the Middle Pleistocenen. Current Anthropology, 15 (4): 508-14.

- (1977): Olorgesailie. Archaeological Studies of a Middle Pleistocene Lake Basin in Kenya. University Press. Chicago.

- (1978): «Early man reviewed». Nature, 273: 588-589.

IsAAC, G. L. and CuRTIS, G. H. (1974): "Age of the Early Acheulian from the Peninj Group, Tanzania». Nature, 249: 624-627.

Islamov, U. I. (1990): «Sel'oungour un nouveau site du Paléolithique inférieur en Asie Centrale». L'Anthropologie, 94 (4): 675-688.

Islamov, U. I.; Zubov, A. A. and Kharitonov, V. M. (1988): «Paleoliticheskaia Stoianka Sel'ungur v ferganskoi doliniew. Voprosy Antropologii, 80: 38-49.

Ivanova, I. K. (1982): «Iskopaemyi Chelovek i ego Kul'tura». In E. V. Shantser (ed.): Chetvertichnaia sistema. Nedra. Moscow: 382-412.

JAEGER, J. J. (1975): "The mammalian faunas and hominid fossils of the middle Pleistocene of the Maghreb». In K. Butzer and G. Isaac (eds.): After the Australopithecines. Mouton. The Hague: 399-418.

- (1983): «Le gisement d'Ubeidiya, importance et age». Paléorient, 9 (1): 89-90.

DE-XIN, J. (1988): "Quaternary palynofloras and palaeoclimate of Qaidam Basin, Qinghai». In P. Whyte (ed.): The Palaeoenvironment of East Asia from the mid-Tertiary. Centre of Asian Studies. Hong Kong: 571-578.

KAHLKE, H. D. (1986): "Corrélations biostratigraphiques entre les sites à hominidés anciens d'Eurasie». L'Anthropologie, 90 (3): $401-405$.

KAPELMAN, J. (1984): "Plio-Pleistocene environments of Bed I and lower Bed II, Olduvai Gorge, Tanzania». Palaeogeography, Palaeoclimatology, Palaeoecology, 48: 171-196.

Kelling, G. and Stanley, J. D. (1972): «Sedimentation in the vicinity of the Strait of Gibraltarn. In D. J. Stanley (ed.): The Mediterranean Sea: A Natural Sedimentation Laboratory: Dowden, Hutchinson and Ross. Stroudsburg: 489-519.

KozlowskI, J. (1987): «Discussion of R. Davis "Improved, Chronological determinations for Soviet Central Asian" Palaeolithicw. In H. L. Dibble and A. Montet-White (eds.): Upper Pleistocene Prehistory of Western Eurasia. University of Pennsylvania Museum. Philadelphia: 301.

KretzoI, M. (1961-64): «Mammal faunae and the continental geology of India». Acta Geologica Academiae Scientarum Hungarica, 7-8; 301-312.

Kretzol, M. and VÉRTES, L. (1965): «Upper Biharian (Intermindel) Pebble-Industry occupation site in Western Hungarym. Current Anthropology, 6 (1): 74-87.

KUKLA, G. J. (1975): «Loess stratigraphy of Central Europe». In K. Butzer and G. Isaac (eds.): After the Australopithecines. Mouton. The Hague: 99-188.

- (1978): «The classical European glacial stages: correlation with deep-sea sediments». Transactions of the Nebraska Academy of Sciences, VI: 57-93.

- (1987): "Pleistocene climates in China and Europe compared to oxygen isotope record». Palaeoecology of Africa, 18: 37-45.

KulaKovSKaiA, L. V. (1989): Musterskie Kul'tury Karpatskogo Basseina. Naukova Dumka. Kiev.

KurTÉn, B. (1957): «Mammal migrations, Cenozoic stratigraphy, and the age of Peking Man and the Australopithecinesw. Journal of Paleontology, 31: 215-227. 
- (1968): Pleistocene Mammals of Europe. Wiedenfeld and Nicolson. London.

- (1971): „Fossil Hyanidae from the early excavations at Stránská Skálaw. In E. Musil (ed.): Stränská Skála I, 1910-1945. Moravské museum-Ustav Anthropos. Vydava: 113-120.

Laming-Emperaire, A. (1978): «Notes sur le Paléolithique inférieur de Sibérie et sur ses rapports avec la préhistoire Américainew. Inter-Nord, 15: 220-224.

LACK, D. (1970): The Natural Regulation of Animal Numbers. Clarendon Press. Oxford.

LANPO, J. (1980): Early Man in China. Foreign Language Press, Beijing.

LANPO, J. and QI, W. (1987): «Artefacts lithiques provenant du site Pléistocène ancien de Donggutuo près de Nihewan (Nohiwan), province d'Hebei, Chinex. L'Anthropologie, 91 (3): 727-732.

Lévi-Strauss, C. (1958): «Race and Historyn. In UNESCO (ed.); The Race Question in Modern Science. UNESCO. Paris.

Lindsay, E. H.; Opdyke, N. D. and Johnson, N. M. (1980): "Pliocene dispersal of the horse EQUUS and late Cenozoic mammalian dispersal eventsn. Nature, 287: 135-138.

LiUBiN, V. P. (1984): «Glava vtoraia pannii paleolit Kavkaza». In Arkheologiia S.S.S.P.-Paleolit S.S.S.R. Izdatel'stvo «Naukan. Moscow: 45-93.

- (1989): «Nizhnii Paleolit». In Paleolit Kabkana i Severnoi Azii Akademiia Nauk S.S.S.R. Leningrad: 9-92.

López Martínez, N. (1972): "Los macromamíferos del Cuaternario de Rincón de la Victorian. Boletín de la $R$. Sociedad de Historia Natural (Geologia), 70: 223-233.

López Martinez, N. and Ruiz Bustos, A. (1977): «Descubrimiento de dos Yacimientos del Pleistoceno medio en el Karst de la Sierra Alfaguara (Granada). Sintesis estratigráfica de este periodo en la región Bétican. Estudios Geológicos, 33: 255-265.

EUmLeY, H. DE (1976): «Les premières industries humaines en Provencew. In H. de Lumley (ed.): La Préhistoire Française. C.N.R.S. Paris, I: 765-776.

- (ed.) (1982): Les premiers habitants de l'Europe. Laboratoire de Préhistoire du Musée de l'Homme, Paris.

Lumley, H. DE; Fournier, A.; KrzePKOWSKA, J. and Echassoux, A. (1988): «L'industrie du Pléistocène inférieur de la grotte du Vallonet, Roquebrune-Cap-Martin, Alpes Maritimesw. L'Anthropologie, 90 (2): 501-614.

MagLio, V. J. (1975): «Pleistocene faunal evolution in Africa and Eurasia». In K. Butzer and G. Isaac (eds.): After the Australopithecines. Mouton. The Hague: 419-476.

- (1978): «Patterns of faunal evoution». In V. J. Maglio and H. B. S. Cooke (eds.): Evolution of African Mammals. Harvard University Press. Cambridge: 603-619.

MAREAN, C. W. (1969): «Sabertooth cats and their relevance for early hominid diet and evolution". Journal of Human Evolution, 18: 559-582.

MARTIN, P. S. (1986): «Prehistoric overkill: the global model». In P. S. Martin and R. G. Klein (eds.): Quaternary Extinctions. A Prehistoric Revolution. University of Arizona Press. Tucson: 354-403.

McBurney, Ch. B. M. (1975): "Current status of the Lower and Middle Palaeolithic of the entire region from the Levant through North African. In F. Wendorf and A. E. Marks (eds.): Problems in Prehistory: North Africa and the Levant. Southern Methodist University Press. Dallas: 411-425.

- (1976): Early Man in the Soviet Union. British Academy. Oxford University Press. 55 pp.

MCPherron, A. and Schmidt, V. (1983): "Palaeomagnetic dating at Isernia La Pineta". In C. Peretto; C. Terzani and M. Cremaschi (eds.): Isernia La Pineta. Calderini. Bologna: 67-69.

Meignen, L. (1983): «Review of Naama Goren "The lithic assemblages of the site of "Ubeidiya, Jordan Valley". Doctoral thesis. Hebrew University. Jerusalem.

Minzoni-Deroche, A. and Sanlaville, P. (1988): "Le Paléolithique inférieur de la région de Gaziantep». Paléorient, 14 (2): 87-98.

Misra, V. N. (1989): «Stone Age India: an ecological perspective». Man and Environment, 14 (1): 17-64.

MoNTAGU, A. (1964): "Natural selection and man's relative hairlessness". Journal of the American Medical Association, 87: 356-357.

Movius, H. L. (1944): "Early Man and Pleistocene stratigraphy in Southern and Eastern Asia". Papers of the Peabody Museum of American Archaeology and Etnology, Harvard University, 19 (3): 3-125.

- (1948): "The Lower Palaeolithic cultures of Southern and Eastern Asia". Transactions of the American Philosophical Society, 38: 329-420.

- (1953): "The Mousterian cave of Teshik-Tash, Southeastern Uzbekistan, Central Asia», American School of Prehistoric Research, 17: 11-71.

- (1978): «Southern and Eastern Asia: Conclusionsw. In F. Ikawa-Smith (ed.): Early Palaeolithic in South and East Asia. Mouton. The Hague: 351-355.

MoYÁ-SOLÁ, S. and AGUSTf, J. (1989): «Una reinterpretación del fragmento craneal de Orce: Equus stenonis». In J. G. Clols, D. Campillo Valero and E. Garcia Olivares (eds.): Los restos humanos de Orce y Cueva Victoria. Institut Paleontologic. Barcelona: 447-451.

Muhesen, S. (1981): "The upper Acheulian in Syriaw. In P. Sanlaville and J. Cauvin (eds.): Prehistoire du Levant: C.N.R.S. Paris: 185-191.

- (1988): «Le Paléolithique inférieur de Syrie». L'Anthropologie, 92 (3): 863-882.

MusIl, R. (ed.) (1971): Stránská Skála 1910-1945. Moravské Museum-Ustav. Anthropos. Výdava.

Mussi, M. (1990): «Continuity and change at the Last Glacial Maximum». In O. Soffer and C. Gamble (eds.): The World at 18.000 B.P. Unwin Hyman, London, 1: 126-147.

T. P., 1992, $\mathrm{n}^{2} 49$ 
NARr, Karl J. (1953): “Zur Freage altpaläolitischer Kulturkreise». Anthropos, 48: 773-784.

OAKLEY, K. P. (1961): Man the Toolmaker. Phoenix. Chicago.

- (1964): Frameuorks for Dating Fossil Man. Wiedenfeld and Nicolson. London.

- (1972): Man the Toolmaker, 6th edition. Phoenix. Chicago.

OнЕ., М. (1979): "The Clactonian: an independent complex or an integral part of the Acheulian?". Current Anthropologv, 20 (4): 685-726.

OKı.adnikov, A. P. (1972): "Découverte du Paléolithique inférieur en Sibérie et en Mongolie». Inter-Nord, 12: 191206.

OPDYKE, N. D.; Lindsay, E. and KUKLA, G. (1983): “Evidence for earlier date of Ubeidiva, Israel hominid siten. Nature, 304: 375-376.

Ozdó̧an, M. and Koyuntu, A. (1986): «1986 Yılı caslısmalarının ilek sonucları ve bazı gözlemlen. Arkeologi ve Sanat, 32/33: 4-17.

Peretto, C. and Piperno, M. (1985): "The early phases of human settlement in Italy». In C. Peretto (ed.) Homo. Journey to the Origins of Man's History: Cataloghi Marsilio. Venice: 82-89.

Peretto, C.; Terzani, C. and Cremaschi, M. (eds.) (1983): Isernia la Pineta: un accampamento più antico di 700.000 anni. Isernia, Museo Nazionale. Calderini, Bologna.

Pérez-GonzÁlez, A. (1980): «El marco geográfico, geológico y geomorfológico de los yacimientos de Aridos en la cuenca del Tajom. In M. Santonja, M. López Martinez and A. Pérez-González (eds.): Ocupaciones Achelenses en el valle del Jarama. Diputación Provincial. Madrid: 15-28.

- (1980): «Geología y estratigrafia de los yacimientos de Aridos en la llanura aluvial de Arganda (Madrid)». In M. Santonja, N. López Martínez and A. Pérez-González (eds.): Ocupaciones Achelenses en el valle del Jarama. Diputación Provincial. Madrid: 49-61.

PERLĖS, C. (1987): «La naissance du feu». L'Histoire, 105: 28-33.

Petrov, M. (1962): "Types de déserts de l'Asie Centralew. Anales de Géographie, 71: 131-155.

Pilbeam, D. R.; Meyer, G. E.; Badgley, C.; Rose, M. D.; Pickford, M. H.; Behrensmeyer, A. K. and Ibrahim Shah, S. M. (1977): «New hominoid primates from the Siwaliks of Pakistan and their bearing on hominoid evolution». Nature, 270: 689-695.

PiPERNO, M. (1972): «The Monte Peglia industry». Quaternaria, 16: 53-65.

- (1989): «Preistoria». In Volume VIII della Enciclopedia del Novecento. Istituto della Enciclopedia Italiana: 864 . 872.

Piperno, M.; Bulgarelli, G. M. and Zevi, F. (eds.) (1985): I primi abitanti d'Europa. De Luca Editore. Rome.

Piperno, M. and Segre, A. (1982): «Pleistocene e Paleolitico inferiore di Venosa: nuove ricerche». In A. Broglio, A. Palma di Cesnola and A. M. Radmilli (eds.): Il Paleolitico inferiore in Italia. Atti della XXIII riunione scientifica (Firenze, 1980). Istituto Italiano di preistoria e protostoria, Florence: 589-596.

PoPE, G. G. (1984): "The antiquity and paleoenvironment of the Asian Hominidaen. In R. D. White (ed.): The Evolution of the East Asian Environment. Centre of Asian Studies. Hong Kong: 822-847.

- (1988): "Current issues in Far Eastern palaeoanthropology". In P. White (ed.): The Paleoenvironment o East Asia from the mid-Tertiary. Centre of Asian Studies. Hong Kong: 1.097-1.123.

Pope, G. G. and CronIN, J. E. (1984): "The Asian Hominidae», Journal of Human Evolution, 13: 377-396.

Pope, G. G.; Nakabanlarg, S. and Pitragool, S. (1987): "Le Paléolithique du Nord de la Thaïlande. Découvertes et perspectives nouvelles". L'Anthropologie, 91 (3): 749-754.

PoTtS, R. (1984): "Home bases and early hominids". American Scientist, 72: 338-347.

POWERS, R. (1973): "Palaeolithic man in Northeast Asia». Arctic Anthropology, X (2): 1-106.

Querol, M. A. and Santonja, M. (1983): El yacimiento de cantos trabajados de El Aculadero (Puerto de Santa Maria, Cádiz). Ministerio de Cultura. Madrid.

QI, W. (1988): «Le cadre stratigraphique, géochronologique et biostratigraphique des sites les plus anciens connus en Chine". L'Anthropologie, 92 (3): 931-938.

RAMENDO, L. (1963): "Les galets aménagés de Reggan (Sahara)». Lybica (Alger) 11: 43-74.

RANOV, V. A. (1972): «Le peuplement préhistorique de la Haute-Asie». L'Anthropologie, 76 (1-2): 5-20.

- (1976): "The Palaeolithic of the Central Asia: a revision». In A. Ghosh (ed.): Le Paléolithique inferieur et moyen en Inde, en Asie Centrale et dans le Sud-Est Asiatique. Union International des Sciences Prehistoriques et Protohistoriques, IXe Congrs (Nice): 91-129.

- (1982): «Early Palaeolithic Karatov Culture in Southern Tadjikistan». XI INQUA Congress (Moscow 1982). Abstracts vol. II: 259.

- (1984): «Douzes années de recherches sur la préhistoire au Tadjikistan méridional et au Pamir (1971-1982)». Paléorient, 10/2: 5-21.

Ranov, V. A. and Richard, S. D. (1979): "Toward a new outline of the Soviet Central Asian Palaeolithic". Current Anthropology, 20 (2): 249-270.

Ranov, V. A.; Dodonov, A. E.; Lomov, S. P.; Pakhomov, M. M. and Pen'kov, A. V. (1987): "Kul'dara-novyi nizhnepaleoliticheskii pamiatnik iuzhnovo Tadzhikistana». Biuletin komissii po izucheniu Chetvertichnaia perioda, 56: 65-75.

Raynal, J. P.; Texier, J. P. and Lefebvre, D. (1986): «Essai de correlation de l'océan au continent pour le Quaternaire du Marocm. Revue de Géologie dynamique et de Géographie physique, 27 (2): 141-147. 
Raynal, J. P.; Texier, J. P.; Lefebvre, D. and Fedoroff, N. (1986): «Quaternary paleoenvironments and palaeoclimates of Moroccon. In Quaternary Climate in Western Mediterranean: 503-515.

Redman, Ch. L. (1978): The Rise of Civilization. From Early Farmers to Urban Society in the Ancient Near East. W. H. Freeman. San Francisco.

RePEnNing, CH. A. (1967): „Palearctic-Nearctic mammalian dispersal in the Late Cenozoic». In D. M. Hopkins (ed.): The Bering Land Bridge. University Press. Stanford: 288-311.

Repenning, CH. A. and FeJfar, O. (1982): «Evidence for earlier date of 'Ubeidiya, Israel, hominid siten. Nature, 299: 344-347.

RIET LowE, C. VAN (1932): «The prehistory of South Africa in relation to that of Western Europew. South African Journal of Science, 29: 756-764.

- (1945): «Evolution of the levallois technique in South African. Man, 65: 45-59.

Ripoll Perelló, E. (1983): «Buscando nuestros orígenes». Revista de Arqueología, 29: 5-6.

Ripoll López, S. and Cacho Quesada, C. (1990): «Le Solutréen dans le Sud de la Péninsule Ibériquen. In J. K. Kozlowski (ed.): Feuilles de Pierre. Les industries à pointes foliacées du Paléolithique supérieur européen. Etudes et Recherches archéologiques de l'Université de Liège. Liège. 42: 449-465.

Roche, H. and TIERCELIN, J. J. (1977): «Découverte d'une industrie lithique ancienne in situ dans la formation d'Hadar, Afar Central, Ethiopien. Comptes Rendus de l'Académie des Sciences de Paris, 284 (Série D): 1.871 1.874 .

ROE, D. A. (1964): «The British Lower and Middle Palaeolithic: some problemsw. Proceedings of the Prehistoric Society, 30: 245-267.

- (1981): The Lower and Middle Palaeolithic Periods in Britain. Routledge and Kegan Paul. London.

RoLLAND, Nicolas (1978): «The interpretation of Euro-African distributional features during the Early Palaeolithic". In P. G. Duke, J. Ebert, G. Langemann and A. P. Buchner (eds.): Diffusion and Migration. Their Roles in Cultural Development. Archaeological Association. University of Calgary. Calgary: 125-143.

- (1983): «Out of Africa: a review of the initial peopling of Western Eurasian. XIIth International Conference of Anthropological and Ethnological Sciences. Vancouver, August 20-25.

- (1986): «Recent findings from La Micoque and other sites in South-Western and Mediterranean France: their bearing on the "Tayacian" problem and Middle Palaeolithic emergencew. In G. N. Bailey and P. Callow (eds.) Stone Age Prehistory. Cambridge University Press: 121-151.

Rouse, I. (1986): Migrations in Prehistory. Yale University Press. New Haven.

Ruiz Bustos, A. and Michaux, J. (1976): «Le site préhistorique nouveau de Cúllar de Baza I (province de Grenade, Espagne) d'áge pléistocène moyen. Etude préliminaire et analyse de la faune des rongeurs». Géologie Méditerranéenne, III (3): 173-182.

SavaGe, R. J. G. (1978): "Carnivora". In V. J. Maglio and H. B. S. Cooke (eds.): Evolution of African Mammals. Harvard University Press. Cambridge: 249-267.

SALA, B. (1983): "La fauna del giacimento di Isernia La Pineta». In C. Peretto, C. Terzani and M. Cremaschi (eds.): Isernia La Pineta. Calderini. Bologna: 71-79.

SantonJa, M. (1976): «Industrias del Paleolítico inferior en la Meseta española». Trabajos de Prehistoria, 33: 121165.

- (1981): «Características generales del Paleolítico inferior de la Meseta española». Numantia: 9-63.

- (1983): «ndicios arcaicos de la presencia humana en el interior de la península ibérican. Revista de Arqueología, 29: 2428 .

Santonja, M. and Querol, M. A. (1982): «Industrias del Paleolítico inferior arcaico en la Meseta española». In Homenaje a C. Fernández Chicarro. Ministerio de Cultura. Madrid: 19-29.

Santonja, M. and Villa, P. (1990): "The Lower Palaeolithic of Spain and Portugal». Journal of World Prehistory, 4 (1): $45-94$.

ScHOTT, G. (1971): «Die Hyänen der mosbacher Sande (Altpleistozän, Wiesbaden/Hessen) mit cinem Beitrag zur Stammesgeschichte der Gattung». Crocuta. Mainzer Naturwissenschaftliches Archiv, 10: 29-76.

Segre, A. (1978): «ll Pleistoceno ed il Paleolitico della Basilicataw. In Atti della XX riunione scientifica (Basilicata, 1976): Istituto italiano di preistoria e protostoria. Florence: 15-39.

- (1982): «Discussionew. In A. Broglio, A. Palma di Cesnola and A. M. Radmilli (eds.): Il Paleolitico inferiore in Italia. Atti della XXIII riunione scientifica. Istituto italiano di preistoira protostoria. Florence 587.

- (1984): "Considerazioni sulla cronostratigrafia del Pleistocene lazialew. In Atti della XXIV riunione scientifica (Lazio, 1982): Istituto Italiano di preistoria e protostoria. Florence: 23-30.

Segre, A. and Ascenzi, A. (1984): „Fontana Ranuccio: Italy's earliest middle Pleistocene hominid site». Current Anthropology, 25 (2): 230-233.

SEgRE, A. and BIDDIrTU, I. (1981): «Paleolitico inferiore: le piú antiche tracce dell'attivita umana sulla valle del Saccow. In Quaderni del centro di studio per l'archeologia etrusco-italica, "Archaeologia Laziale IV-Quarto incontro di studio del Comitato per l'archeologia Laziale. Consiglio Nazionale delle Ricerche: 26-34.

Segre, A.; Biddrtú, I. and PIPERNo, M. (1982): «Il Paleolitico inferiore nel Lazio, nella Basilicata e in Sicilia». In A. Broglio, A. Palma di Cesnola and A. M. Radmilli (eds.): Il Paleolitico inferiore in Italia. Atti della XXIII riunione scientifica (Firenze, 1980). Istituto italiano di preistoria e protostoria. Florence.

Sevink, J.; HebedA, E. H.; Priem, H. N. A. and Verschure, R. H. (1981): «A note on an approximately 730.000-year- 
old mammal fauna and associated human activity sites near Isernia, Central Italy». Journal of Archaeological Science, 8: 105-106.

SHER, A. (1975): «Die nördlichste Variante der "Mindel”-Fauna in Eurasien und der Ursprung der subarktischen Mammaliern. Quartärpalaontologie, 1: 235-242.

ShipMAN, P. (1986): "Scavenging or hunting in early hominids: theoretical framework and tests». American Anthropologist, 88 (1): 27-43.

SIENER, G. and HoROwITZ, A. (1974): «Radiometric ages of late Cairozoic basalts from northern Israel; chronostratigraphic implications». Nature, 250: 23-26.

SIMPSON, G. G. (1940): «Mammals and land bridges». Journal of the Washington Academy of Sciences, 30 (4): 137. 163.

- (1962): Evolution and Geography. An Essay on Historical Biogeography with Special Reference to Mammals. Oregon State System of Higher Education. Eugene.

Simpson, G. G. and William, S. Beck (1965): Life. An Introduction to Biology. Harcourt, Brace and World. New York.

SIEVEKING, A. DE G. (1962): "The Palaeolithic industry of Kota Tampan, Perak, Malaya". Proceedings of the Prehistoric Society, 28; 107-139.

SINGER, R. and WYMER, J. J. (1978): «A handaxe from Northwest Iran: the question of human movements between Africa and Asia in the Lower Palaeolithic period". In L. G. Freeman (ed.): Views of the Past: Essays in Old World Prehistory and Palaeoanthropology. Mouton. The Hague: 13-27.

Sмгтн, Ph. E. L. (1986): Palaeolithic Archaeology in Iran. The University of Pennsylvania Museum. Philadelphia

SOLECKI, R. S. and SolECKI, R. L. (1966): «New data from Yabroud, Syria, preliminary report of the Columbia University archaeological investigationsw. Annales Archeologiques Arabes Syriennes, 16 (2): 121-165.

Solmeim, W. (1970): «Northern Thailand, Southeast Asia, and World Prehistory». Asian Perspectives, 13: $145-162$.

SPOONER, Brian (1972): «The Iranian deserts». In B. Spooner (ed.): Population Growth: Anthropological Implications. M.I.T. Press. Cambridge: 245-268.

StANLEY, D. J. (ed.) (1972): The Mediterranean Sea: A Natural Sedimentation Laboratory. Dowden, Hutchinson and Ross. Stroudsburg.

STILES, D. (1979): «Early Acheulian and Developed Oldowan». Current Anthropology, 20: 126-129.

SvoвоDA, J. (1980): "Quelques industries du Paléolithique inférieur en Bohème du Nord. Approche analytique». Anthropologie (Brno), 18: 269-286.

- (1984): "Cadre chronologique et tendances évolutives du Paléolithique tchécoslovaque. Essai de synthèsen. L'Anthropologie, 88 (2): 169-192.

TCHERnOV, E. (1887): "The age of the 'Ubeidiya Formation, an Early Pleistocene hominid site in the Jordan Valley, Israelw. Israel Journal of Earth Sciences, 36: 3-30.

- (1988): «La biochronologie du site de 'Ubeidiya (Vallée du Jourdain) et les plus anciens hominidés du Levant". L'Anthropologie, 92 (3): 839-861.

- (1988): "The age of 'Ubeidiya Formation (Jordan Valley, Israel) and the earliest hominids in the Levant». Paléorient, 14 (2): 63-65.

Teilhard de Chardin, P. (1953): "The idea of fossil man». In S. Tax (ed.): Anthropology Today. Phoenix. Chicago: 31-38.

- (1956): «Oeuvres de Pierre Teilhard de Chardin. Vol. 2. L'apparition de l'homme». Seuil. Paris.

TEXIER, P. J. (1985): "Chilhac III: un gisement paléontologique villafranchien soliflué?». Bulletin de la Société Préhistorique Française, 82 (3): 68-70.

Texier, J. P.; Raynal, J. P. and Lefebvre, D. (1985): "Nouvelles propositions pour un cadre chronologique raisonné du Quaternaire marocain». Comptes Rendus de l'Académie des Sciences de Paris, 301 (Série II, n 3): 183-188.

- (1986): "Thoughts on the Quaternary Chronology of Moroccow. In Quaternary Climate in Western Mediterranean: 487-502.

THALER, L. (1973): «Nanisme et gigantisme insulaires». La Recherche, 4 (37): 741-750.

ThenIUS, E. (1971): «Die Feliden (Carnivora) aus dem Pleistozăn von Stránská Skála». In R. Musil (ed.): Stránská Skála I 1910-1945. Moravské museum-Ûstav Anthropos, Výdava 121: 135.

Thouveny, N. and Bonifay, E. (1984): «New chronological data on European Plio-Pleistocene faunas and hominid occupation sites". Nature, 308: 355-358.

TrXIER, J. (1957): "Le hachereau dans l'Acheuléen nord-africain». Congrès préhistorique de France. Comptes rendus de la XVe session (1956): 914-923.

TORRENCE, R. (1983): "Time budgeting and hunter-gatherer technology». In G. M. Bailey (ed.): Hunter-Gatherer Economy in Prehistory. Cambridge University Press: 11-22.

Tотн, N. (1985): "The Oldowan reassessed: a close look at early stone artifacts". Journal of Archaeological Science, 12: 101-120.

TozzI, C. (1978-81): «Il Paleolitico inferiore del carso triestino". Atti della Societa per la Preistoira e protostoria della Regione Friuli Venezia Giulia, 4: 163-169.

- (1984): "Il riparo di Visogliano e il Paleolitico del carso triestino". In Atti del convegno internazionale "preistoria del caput adriae*, Trieste 19-20, novembre 1983: 6 pp.

T. P., 1992, $\mathrm{n}^{2} 49$ 
- (1990) (in press): "Visogliano e i primi insediamenti nel carso di Triestem. In Colloquio di Forli «Il piu antico popolamento della valle padana nel quadro delle conoscenze Europeen: 16 pp.

Tuffreau, A. (1987): Le Paleolithique inférieur et moven du Nord de la France (Nord, Pas-de-Calais, Picardie) dans son cadre stratigraphique. Thèse de Doctorat d'État. Université des Sciences et Techniques de Lille, Flandre et Artois.

TURNER, A. (1982): «Hominids and fellow travellersw. South A/rican Journal of Science, 78: 231-237.

- (1985): "Extinction, speciation and dispersal in African larger carnivores, from the late Miocene to Recent". South African Journal of Science, 81: 256-257.

VALOCH, K. (1968): "Evolution of the Paleolithic in Central and Eastern Europen. Current Anthropology, 9: 351390.

- (1976): «Aperçu des premières industries en Europe”. In K. Valoch (ed.) Les premières industries de l'Europe. Colloque VIII - IX' Congrès UISPP (Nice, 1976): 178-183.

- (1984): «Early Palacolithic in Moravian. Proceedings of the Prehistoric Society, 50: 63-69.

Vangengeim, E. A. and Shf.R, A. V. (1970): "Siberian equivalents of the Tiraspol faunal complex". Palaeogeography, Palaeoclimatologv, Palaeoecologv, 8 (2/3): 197-207.

Vaufrey, R. (1929): Les éléphañts nains des iles méditerranéennes et la question des isthmes pléistocènes. Archives de l'Institut de Paléontologie Humaine. Mémoire 6. Masson. Paris.

Velichko, A. P. (1984): „Late Pleistocene spatial palaeoclimatic reconstructions». In A. P. Velichko (ed.): Late Quaternary Environments of the Soviet Union. University of Minnesota Press. Minneapolis: 261-285.

VERTES, L. (1965): «Typology of the Buda industry». Quaternaria, 7: 185-195.

VereshChagin, N. K. (1967): Mammals of the Caucasus. Israel Program for Scientific Translations. Jerusalem.

Vflla, P. (1983): Terra Amata and the Middle Pleistocene. Archaeological Record of Southern France. University of California, *Anthropology», 13. Berkeley.

Villaverde Bonilla, V. and Fullola Pericot, J. M. (1990): "Le Solutréen de la zone méditerranéenne espagnole». In J. K. Kozlowski (ed.): Feuilles de Pierre. Les industries à pointes foliacées du Paléolithiques supérieur européen. Etudes et Recherches archéologiques de l'Université de Liège, 42. Liège: 467-480.

VYSHNYATSKY, L. B. (1989): "The discovery of Palaeolithic handaxes in Western Turkmenia: a preliminary report". Paleorient, 15: 95-98.

- (1989): "The Movius' theory and the Palaeolithic of Soviet Central Asia (with special reference to some recent finds in Turkmenia)». Journal of Central Asia, 12 (2): 21-50.

Wang, K; Menglin, D; ZhaOmin, Y. and Huimin, L. (1988): "The loess in the middle reaches of the Yellow River of China and its palaeogeographic environmentw. In P. White (ed.): The Palaeoenvironment of East Asia from the Mid-Tertiary. University of Hong Kong. Centre of Asian Studies, I: 433-444.

WANG, P. (1984): «Progress in late Cenozoic palaeoclimatology of China: a brief reviewn. In R. O. White (ed.): The Evolution of the East Asian Environment. University of Hong Kong. Centre of Asian Studies, I: $165-187$.

Watanabe, H. (1985): "The Chopper-Chopping Tool Complex of Eastern Asian ethnoarchaeological-ecological reexamination». Journal of Anthropological Archaeology, 4: 1-18.

WEINER, J. S. (1971): Man's Natural History. Wiedenfeld and Nicolson. London.

Whiting, J. W. M., Sodergren, J. A. and Stigler, S. M. (1982): "Winter temperature as a constraint to the migration of preindustrial peoplesw. American Anthropologist, 84 (2): 279-298.

WoBst, M. (1976): "Locational relationships in Palaeolithic Society». Journal of Human Evolution, 5: 49-58.

XU, R. (1984): "Changes of the vegetation of China since the late Tertiary". In R. O. White (ed.): The Evolution of the East Asian Environment. University of Hong Kong. Centre of Asian Studies, II: 426-432.

YalcinkayA, I. (1981): «Le Paléolithique inférieur de Turquiem. In P. Sanlaville and J. Cauvin (eds.): Préhistoire du Levant. C.N.R.S. Paris: 208-217.

YI, S. and Clark, G. A. (1983): "Observations on the Lower Palaeolithic of Northeast Asia". Current Anthropology, 24 (2): 181-202.

Yokoyama, Y.; Bibron, R. and Falguéres, C. (1988): "Datation absolue des planchers stalagmitites de la grotte du Vallonet à Roquebrune-Cap-Martín (Alpes-Maritimes) France, par la résonance de spin électronique (ESR)». L'Anthropologie, 92 (2): 429-436.

ZBYSZEWSKI, G. (1976): «Rapport sur les plus anciennes industries paléolithiques du Portugal». In K. Valoch (ed.): Les premières industries de l'Europe. Cologne VIII-IX UISPP Congrès (Nice, 1976): 96-102.

Zhaо, S. and Jiaming, K. (1984): «Origin and development of the Shamo (sandy deserts) and the Gobi (stony deserts) of Chinaw. In R. O. White (ed.): The Evolution of the East Asian Environment. University of Hong Kong. Centre of Asian Studies, I: 230-251.

ZhANG, L. (1988): "The trend towards dryness in north and western China since the Mid-Pleistocene». In P. White (ed.): "The Palaeoenvironment of East Asia from the Mid-Tertiary. University of Hong Kong. Centre of Asian Studies, I: 445-452.

ZHEN, B. (1988): «Studies of the glacial characteristics and environment of the last glaciation in west China». In P. White (ed.): The Palaeoenvironment of East Asia from the Mid-Tertiary. University of Hong Kong. Centre of Asian Studies, I: 453-463.

ZoHARY, M. (1962): Plant Life of Palestine: Israel and Jordan. Ronald. New York. 
THE PALAEOLITHIC COLONIZATION OF EUROPE: AN ARCHAEOLOGICAL AND...

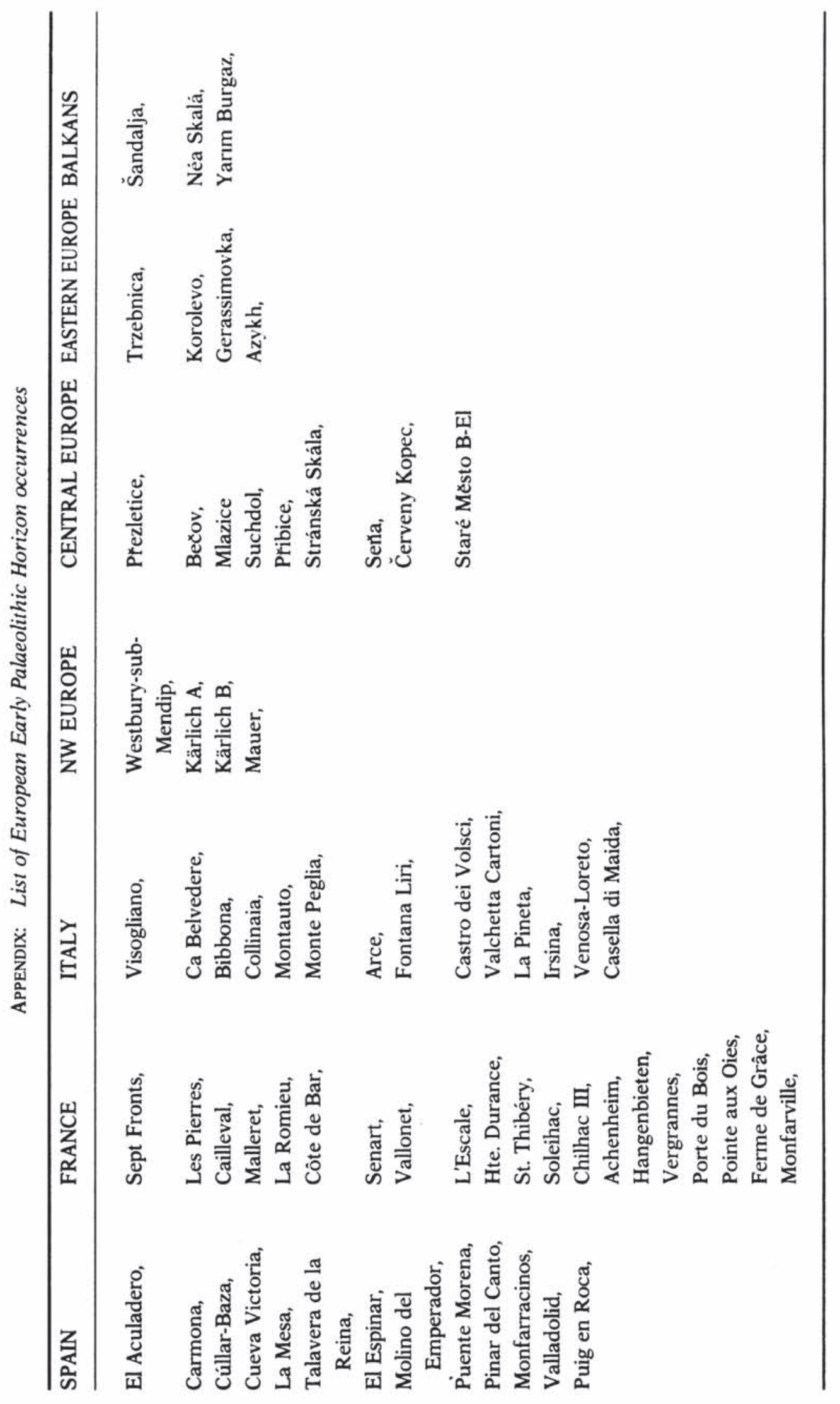

I. P., 1992, $\mathrm{n}^{2} 49$ 